\title{
Dynamic Permeability Related to Greisenization Reactions in Sn-W Ore Deposits: Quantitative Petrophysical and Experimental Evidence
}

\author{
Gaëtan Launay $\mathbb{D}^{\mathrm{D}}$, Stanislas Sizaret, Laurent Guillou-Frottier, Colin Fauguerolles, \\ Rémi Champallier, and Eric Gloaguen
}

Université d'Orléans/CNRS/ISTO/BRGM, UMR 7327, 1 A rue de la Férollerie, 45071 Orléans, France

Correspondence should be addressed to Gaëtan Launay; g.launay@brgm.fr

Received 31 July 2018; Revised 6 November 2018; Accepted 11 December 2018; Published 27 February 2019

Academic Editor: John A. Mavrogenes

Copyright ( 2019 Gaëtan Launay et al. This is an open access article distributed under the Creative Commons Attribution License, which permits unrestricted use, distribution, and reproduction in any medium, provided the original work is properly cited.

\begin{abstract}
Massive greisens are commonly associated with Sn-W mineralization and constitute low-grade high-tonnage deposits. The formation of this type of deposit results from an intense pervasive metasomatic alteration involving a major fluid and mass transfer through a nominally impermeable parental granite. A decrease in the volume of the solid phases associated with the mineral replacement reactions may be a potential process for creating pathways to enhance fluid flow. Here, we explore the effects of the replacement reactions related to greisenization on the granite's mineralogy and petrophysical properties (density, porosity, and permeability), as well as their potential implications for fluid flow in the case of the world-class Panasqueira W-Sn- $(\mathrm{Cu})$ deposit, Portugal. Mineralogical and microtextural analyses of greisenized facies show that the total replacement of feldspars by muscovite is associated with a volume decrease of the solid phases that induces a significant porosity generation in greisen ( 8.5\%). Greisenization experiments coupled with permeability measurements show that the replacement of feldspars by muscovite permits new pathways at the crystal scale that significantly enhance the transient permeability. Moreover, permeability measurements performed on representative samples with different degrees of greisenization show that permeability increases progressively with the level of alteration from $10^{-20} \mathrm{~m}^{2}$ in least granite to $10^{-17} \mathrm{~m}^{2}$ in greisen. The correlation between the permeability and porosity evolutions demonstrates that the porous texture developed during replacement reactions creates new pathways that enhance significantly the permeability in greisen systems. The occurrences of mineral-bearing metals such as cassiterite in the newly formed porosity of greisen provide evidence that greisenization can be a decisive process for enhancing fluid flow and promoting transport of metals in Sn-W deposits. Finally, we present a model involving a positive feedback between greisenization and permeability, in which mineralizing fluids are able to generate their own pathways in initially impermeable granite via replacement reactions, which in turn promote further hydrothermal alteration and mass transport.
\end{abstract}

\section{Introduction}

Greisenization is a common hydrothermal alteration associated with Sn-W and rare metal deposits that are usually spatially and genetically associated with fractionated crustal granitic intrusions [1-4]. This postcrystallization alteration, marked by the breakdown of feldspars and biotite, occurs generally on the cupolas of intrusions during the cooling stage of the granitic intrusions and the first stages of hydrothermal activity. Numerous studies have established that greisenization results from strong interactions between granitic rocks and acidic fluids at temperatures ranging from $250^{\circ} \mathrm{C}$ to $450^{\circ} \mathrm{C}$ [4-8]. These intense fluid-rock interactions lead to complete mineralogical transformation of the granitic rocks by coupled dissolution-precipitation (CDP) reactions $([9-12][13,14])$. Field observations have shown that greisen can form (i) at a local scale adjacent to veins or fractures present in granite, as at Cligga Head [15], and (ii) on a broad scale as massive greisens that are mainly present in the apical portions of mineralized granite, as at Cinovec, East Kemptville, and Panasqueira $[4,16-20]$. These massive greisens may extend to a depth of 200-300 meters and can constitute 
low-grade, high-tonnage deposits marked by a disseminated mineralization $[3,4,21]$. Accordingly, the formation of these massive greisens requires the mass transfer of a large amount of fluid through the initially impermeable granitic rock. This apparent contradiction emphasizes that the permeability of granite intrusions must evolve significantly during the greisenization event to enable an efficient fluid flow.

Recent advances have recognized permeability as a dynamic parameter evolving in response to tectonism, fluid production, and mineralogical reactions $[22,23]$. Depending on the reaction's stoichiometry and on the pressure and temperature conditions, replacement reactions may cause significant negative or positive changes in the total solid volume that can affect significantly fluid flow by changing the permeability [13, 14, 24-28]. Replacement reactions associated with a volumetric increase of the solid phases may lead to the self-sealing of the fluid pathways causing a permeability decrease and hence an inhibition of fluid flow that prevents further hydrothermal alteration. However, in some extreme cases such as serpentinization (hydration of ultramafic rocks), the drastic expansion of the solid phases induced by replacement reactions can generate stress perturbations that trigger microfracturing, which significantly enhances the permeability [29-31]. Conversely, replacement reactions involving a volumetric decrease of the solid phases may be accompanied by porosity and permeability increases that enhance fluid flow. This in turn could enhance mass transport that promotes further hydrothermal alteration and which leads to the pervasive transformation of rocks. Consequently, a change in volume occurring during the replacement reactions can become an efficient process for enhancing the permeability of hydrothermal systems as well as by favoring fracturing and deformation processes. However, the implications of this process for metal transport and hence for the formation of large ore deposits remain poorly constrained.

The process of greisenization has mostly been investigated from the geochemical and mineralogical standpoints. Nevertheless, greisens appear to be generally more porous than do the parental granites from which they formed [16, $17,19,32,33]$. This emphasizes that greisenization can be associated with a significant volumetric decrease of the solid phases. However, the effects of these replacement reactions on the permeability, which can ultimately enhance fluid flow and promote the transport of metals in granitic rocks, need to be investigated and quantified. In the following, we present a complete study that combines mineralogical and microtextural analysis with porosity and density measurements for representative samples of different degrees of greisenization from the world-class Panasqueira W-Sn-(Cu) ore deposit. These measurements of the rocks' petrophysical properties were supplemented by the experimental determination of permeability under realistic hydrothermal conditions representative of their degree of greisenization. Additionally, experimental greisenization coupled with permeability measurement has been performed to establish relationships between the rock-volume decrease induced by the replacement reactions identified by mineralogical study, and the evolution of permeability.
The analysis of these various results provides evidence that greisenization can be a decisive process in enhancing the permeability of granitic rock and thereby promoting metal transport in Sn-W deposits, in the absence of external stress. Accordingly, this may explain the formation of large greisen deposits as well as the efficient transport of metals toward structural traps, as in the lode vein deposits of Panasqueira.

\section{Geological Setting}

2.1. The Panasqueira $W-S n-(\mathrm{Cu})$ Ore Deposit. The W-Sn-(Cu) Panasqueira ore deposit is located in Portugal's Beira Baixa province in the Central Iberian Zone (CIZ), which belongs to the Iberian Variscan belt [34] (Figure 1(a)). This region is mainly underlain by Neoproterozoic schist (Schist-Greywacke Complex) constituting the Beira schist formation, into which a large volume of granite was emplaced during the latest stage of the Variscan orogeny (300 to $280 \mathrm{Ma}$ ) [36-38].

In the Panasqueira district, the Beira schist was affected by thermal metamorphism (spotted schist) related to an underlying S-type granite (Figures 1(b) and 1(c)) [39, 40]. Although this granite does not outcrop, its lateral extent is inferred from the surface distribution of spotted schist and from drill holes distributed across the Panasqueira district (Figure 1(b)). This small intrusive body is characterized by an elliptical shape elongated NW-SE $(7.5 \times 4.5 \mathrm{~km})$ limited by the Cebola fault to the northwest and the Rio Zêzere fault to the southeast (Figure 1(b)) $[18,20,40,41]$. The granite's roof geometry is marked by the presence of a cupola observable only in the underground mine (Figures 1(b) and 1(c)). This cupola and the upper part of the Panasqueira granite have been converted into a massive greisen by an intense metasomatic alteration $[18,20,39,40]$ (Figures 1(b) and $1(c))$. This greisen is extensively mineralized by sulfides (arsenopyrite, chalcopyrite, sphalerite, pyrite, and pyrrhotite) and to a lesser extent by cassiterite and wolframite.

The economic W-Sn mineralization is mainly hosted by a dense network of flat-lying quartz veins, which crosscuts the vertical foliation of the metasedimentary host rock (Beira schist). This ore zone is connected at depth to the greisen cupola and extends over an area of $6 \mathrm{~km}^{2}$ for a depth extension of about 200-300 meters (Figures 1 (b) and 1(c)) [18, 42].

The paragenetic sequence of the vein system at Panasqueira may be grouped into two main stages [18, 20, 42]. The first stage carries the W-Sn mineralization and is composed of muscovite and quartz accompanied by wolframite and cassiterite. The second stage, which postdates the Sn-W stage, carries the $\mathrm{Cu}$ mineralization and consists of arsenopyrite, chalcopyrite, sphalerite pyrite, and pyrrhotite. Based on the geological setting and the analyses of fluid inclusions from the Panasqueira mineralized vein system, the conditions related to the $\mathrm{W}-\mathrm{Sn}$ mineralization stage were estimated at between 300 and $350^{\circ} \mathrm{C}$ and pressures ranging between 20 and $50 \mathrm{MPa}[18,39,42-44]$.

2.2. The Greisen Alteration of the Panasqueira Granite. The SCB2 borehole was drilled in the NE flank of the intrusive body (Figures 1(b) and 1(c)) down to a depth 

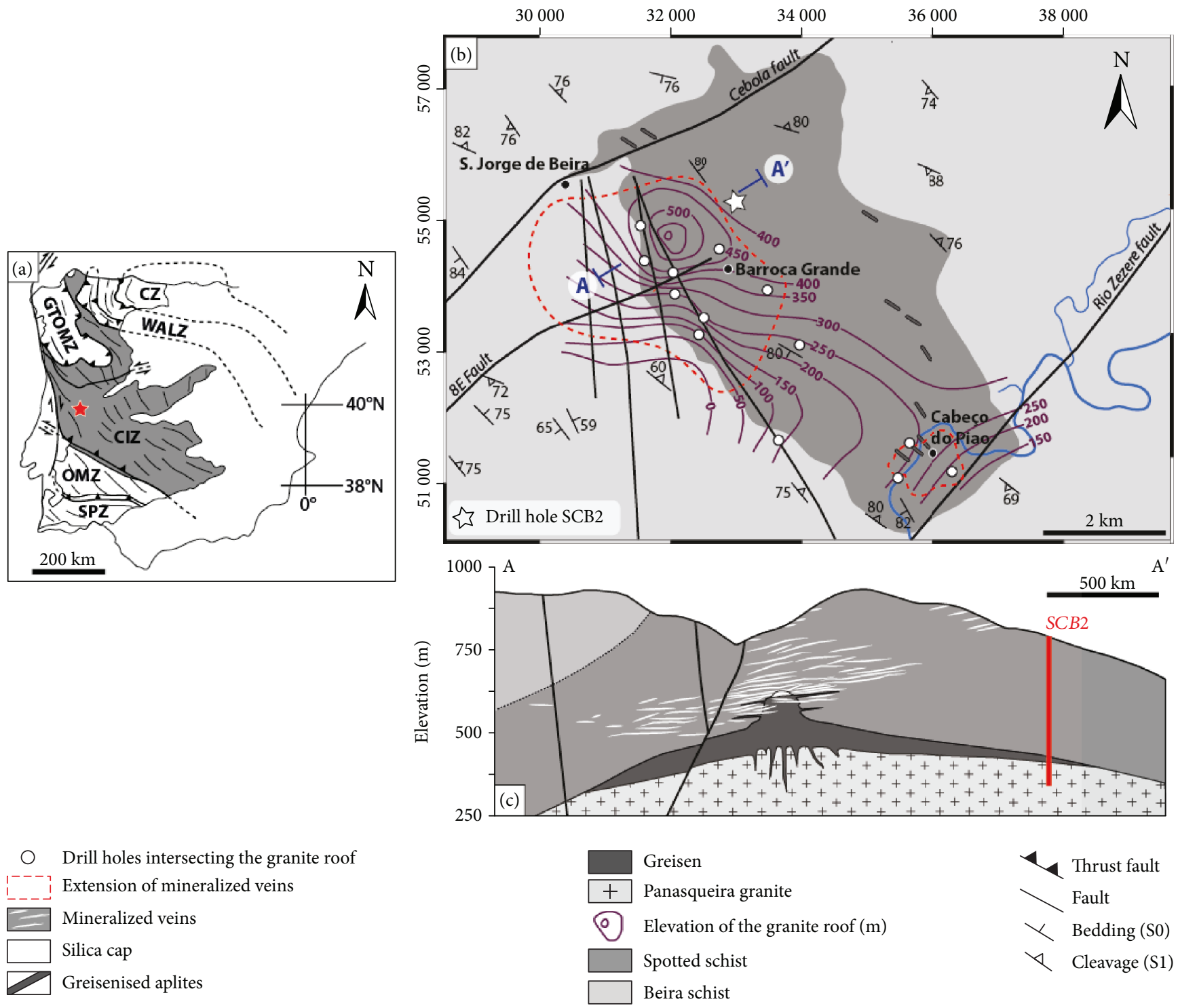

Figure 1: (a) Location of the Panasqueira ore deposit in the Iberian Variscan belt (red star). (b) Geological map of the Panasqueira W-Sn- $(\mathrm{Cu})$ ore deposit including the location of the drill hole SCB2 (white star) used in this study. (c) The (A-A') geological cross section displays the spatial relationship between the mineralized veins and the massive greisen constituting the top of the granite intrusion (data source Beralt Tin \& Wolfram S.A.) (modified from [35]). Abbreviations, CZ: Cantabrian Zone; WALZ: West Asturian-Leonese Zone; GTOMZ: Galicia Tràs-os-Montes Zone; CIZ: Central Iberian Zone; OMZ: Ossa-Morena Zone; SPZ: South Portuguese Zone.

of $400 \mathrm{~m}$. The drill cores display a strong vertical mineral zoning of the granite-greisen lithologies that reflects the progressive transformation of the Panasqueira granite into greisen (Figure 2(a)).

The deeper part of the intrusion exhibits a porphyritic two-mica granite mainly composed of K-feldspar phenocrysts (up to $4 \mathrm{~cm}$ ) and snowball-textured quartz embedded in a matrix of K-feldspar, albite, quartz, biotite, and muscovite (Figure 2(b) photo 4). Accessory minerals include apatite, zircon, and $\mathrm{Fe}-\mathrm{Ti}$ oxides. In this granite, the greisen alteration is present only at a local scale as narrow halos $(1-30 \mathrm{~cm})$ developed along each side of fracture or mineralized veins (Figures 2(a) and 2(b) photo 4).

The upper part of the intrusion consists of a broad massive greisen $(\approx 30 \mathrm{~m}$ thick in drill hole SCB2 $)$, which can become several hundred meters thick in the cupola (Figure 1(c)). In drill hole SCB2, the greisenization increases progressively up to the granite roof, as evidenced by changes in the rock's mineralogical composition (Figure 2(a)). The granite is completely altered and converted into greisen along the granite-schist contact. The presence of granite relics embedded in the massive greisen marks the migration front of this pervasive alteration (Figure 2(b) photos 2 and 3). During this intense hydrothermal alteration, the primary magmatic texture of the Panasqueira granite was completely obliterated by replacement minerals. Feldspars and biotite are totally replaced by an equi-granular, medium-grained quartz-muscovite assemblage characterized by a porous texture suggesting the development of porosity during the greisen alteration (Figure 2(b) photo 1). 


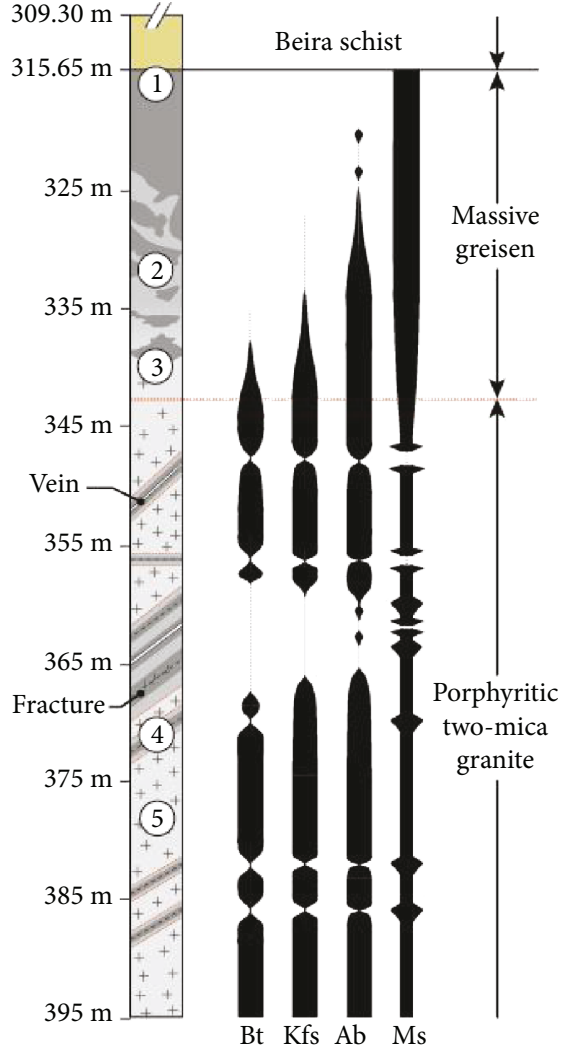

(a)

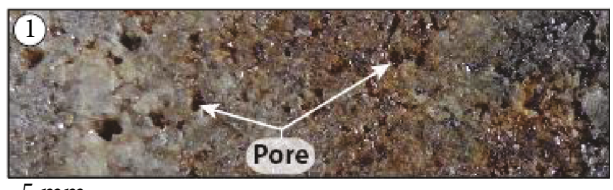

$5 \mathrm{~mm}$
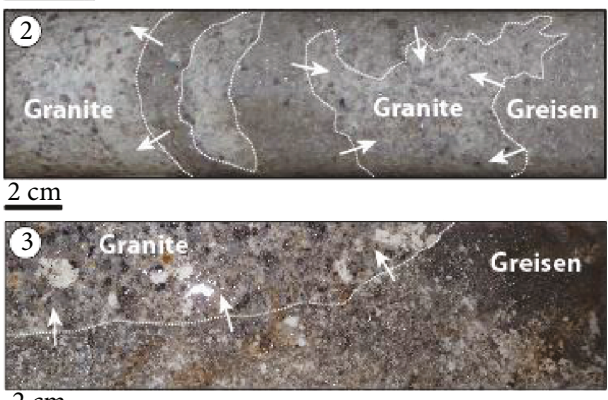

$2 \mathrm{~cm}$
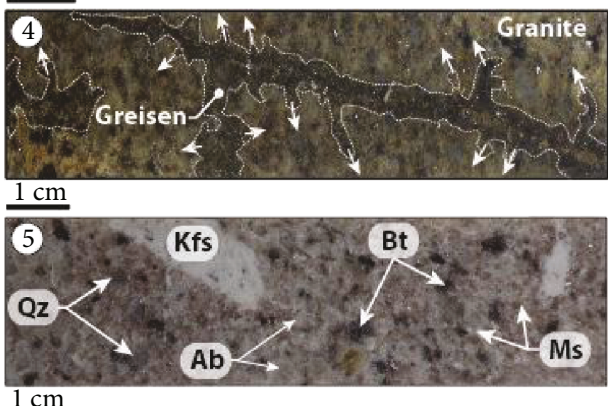

(b)

FIGURE 2: (a) Drill hole SCB2 showing the vertical mineral zoning of the greisen alteration. (b) Macroscopic textural characteristics of (1) facies of the most altered greisen displaying a well-developed porosity, (2) quartz-muscovite greisen in which it is possible to observe pieces of less altered granite (white dashed lines correspond to the alteration front and white arrows to the expected direction of propagation), (3) propagation of the pervasive greisenization toward the Panasqueira granite, (4) propagation of alteration from the fracture in the deeper part of the drill hole, and (5) the porphyritic two-mica granite of Panasqueira. Mineral abbreviations from Whitney and Evans [45]. Ab: albite; Bt: biotite; Kfs: K-feldspar; Ms: muscovite; Qz: quartz.

\section{Materials and Methods}

3.1. Starting Materials. To investigate the influence of the greisen alteration on the petrophysical properties, especially on permeability, five samples of the least altered granite, three samples of the most altered greisen, and eleven samples of greisenized granite with various alteration levels were collected from drill hole SCB2 and within the greisen cupola. To compare greisen's permeability with the background permeability of the metasedimentary host rock and to assess the potential role of greisen as a possible and preferential pathway for mineralized fluids, we collected one additional sample of schist above the granite-schist contact in drill hole SCB2.

3.2. Mineralogical and Microtextural Analysis. The microtextures and microstructures of samples were examined on polished thin sections by optical microscopy (reflected and transmitted light) and by scanning electron microscopy (SEM) using a Zeiss Merlin compact high-resolution scanning electronic microscope equipped with a Gemini I detector (BRGM, University of Orléans). To display alteration textures in natural samples and in experimental alteration products, element mapping was performed by SEM using an acceleration voltage of $15 \mathrm{kV}$.
3.3. Whole Rock Geochemical Analysis. The whole rock major and trace element compositions of the selected samples were determined by inductively coupled plasma atomic emission spectroscopy (ICP-AES) and mass spectrometry (ICP-MS) following the standard analytical procedure of ALS laboratories (http://alsglobal.com/geochemistry).

From these analyses, the relative mobility of elements during the greisen alteration has been used (i) to discuss the mass/volume changes of rocks induced by alteration reactions and (ii) to define a chemical alteration index characterizing the degree of alteration of each sample. This alteration index was then applied to determine the evolution of the petrophysical properties (density, porosity, and permeability) as a function of greisen's degree of alteration.

\subsection{Greisenization Experiment Coupled with Permeability} Measurement. To determine whether replacement reactions involved during the greisen alteration can enhance permeability during the first stage of the alteration and develop new pathways at the mineral scale, we performed a greisenization experiment coupled with permeability measurements. This experiment was conducted in an external heated pressure vessel for which the maximum allowable confining pressure and temperature conditions are $30 \mathrm{MPa}$ and $300^{\circ} \mathrm{C}$. This 


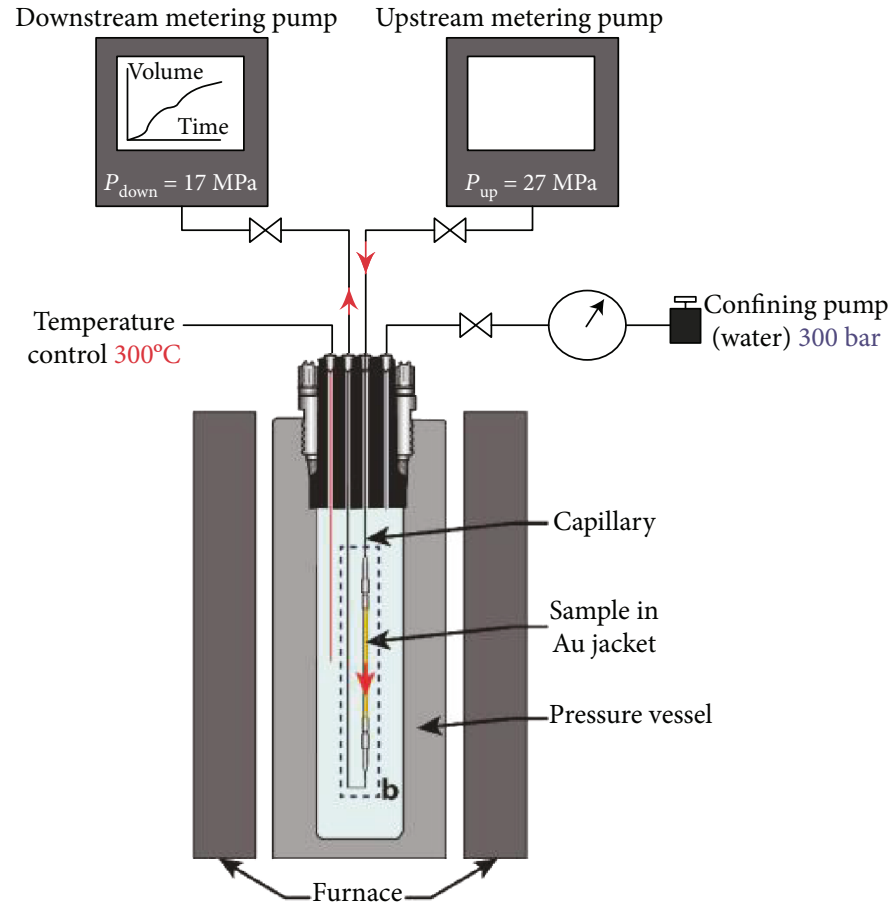

(a)

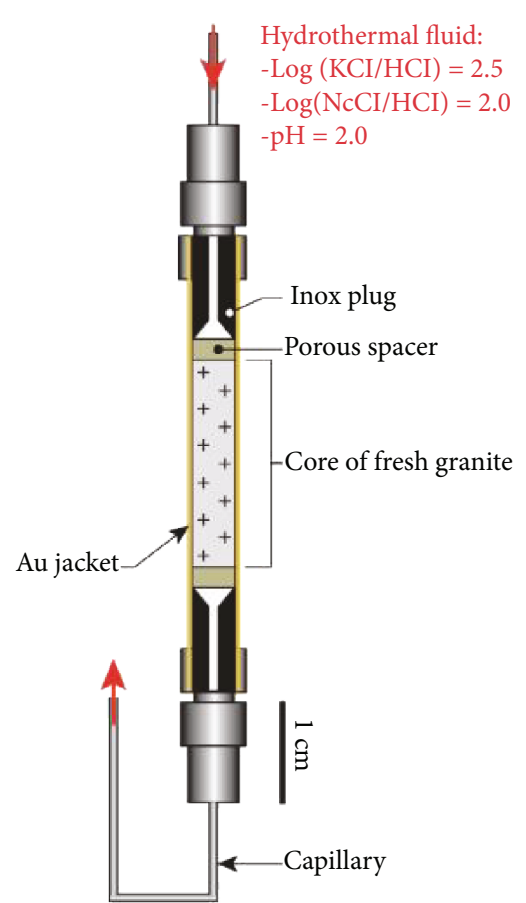

(b)

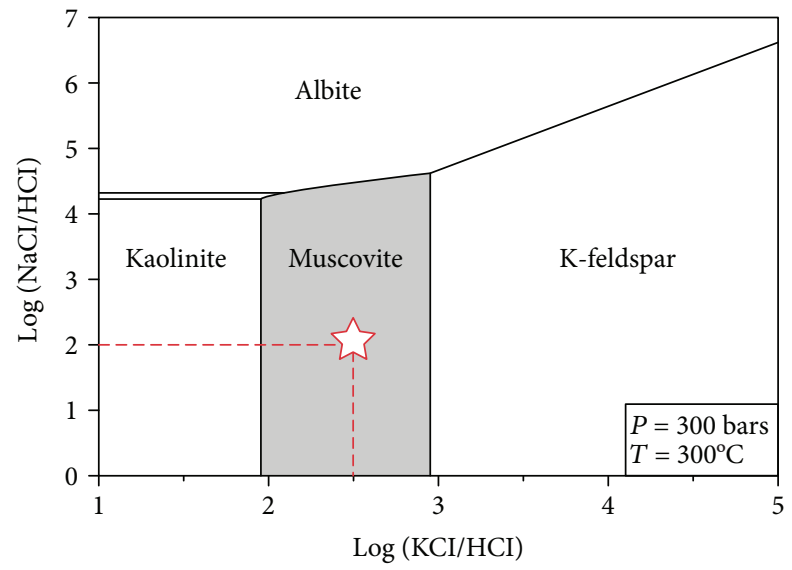

(c)

Figure 3: Apparatus used for the greisenization experiment coupled with permeability measurement. (a) External heated pressure vessel equipped with two metering pumps used for the pore-fluid system and the permeability measurement. (b) Connection between the granite core (encapsulated in the Au jacket) and the pore-fluid system. Red arrows give the sense of fluid flow in the pore-fluid system. (c) $\log (\mathrm{NaCl} / \mathrm{HCl})$ vs. $\log (\mathrm{KCl} / \mathrm{HCl})$ diagram showing the stability fields of albite, muscovite, and $\mathrm{K}$-feldspars under the experimental conditions used for the greisenization experiment $\left(300^{\circ} \mathrm{C}\right.$ and 300 bar). The white star indicates the composition of the starting solution used for the experiment. This diagram was established from the SUPCRTLB thermodynamic database [46, 47].

experimental system includes two metering pumps, which can work at constant fluid pressure condition during the experiment (precision of $\pm 0.01 \mathrm{MPa}$ ) (Figure $3(\mathrm{a})$ ). The fluid flow across the sample was induced by a differential fluid pressure gradient imposed by the two metering pumps, which were also used to record the volume of fluid injected/collected through the core sample over the experimental period. These metering pumps (upstream and downstream) were connected to a gold jacket that contained the granite core (diameter $0.5 \mathrm{~cm}$, length $2 \mathrm{~cm}$ ) (Figure $3(\mathrm{~b})$ ). The ductile nature of gold at the applied pressure and temperature conditions ensures a perfect coupling between the side of the core and the jacket and prevents fluid flow along the sample surface. Permeable ceramic spacers were placed on each end of the core sample to act in the place of spreader plates, ensuring that the fluid impinged on the entire sample area.

The greisenization experiment was conducted for a duration of 20 days at $300^{\circ} \mathrm{C}$ for a confining pressure of $30 \mathrm{MPa}$ and with a differential fluid pressure gradient $(\Delta P)$ of $10 \mathrm{MPa}$ (upstream pump $=27 \mathrm{MPa}$, downstream pump $=17$ $\mathrm{MPa})$. The fluid used for the experiment was characterized by a $\log (\mathrm{mKCl} / \mathrm{mHCl})$ of 2.5 and a $\log (\mathrm{mNaCl} / \mathrm{mHCl})$ of 
2.0 for an initial $\mathrm{pH}$ of 2.0. This fluid-chemical composition was chosen to promote the replacement of feldspars (albite and K-feldspars) by muscovite under the applied experimental conditions, according to the phase diagram shown in Figure 3(c). Once experimental conditions were stabilized, the sample remained for $24 \mathrm{hr}$ under the imposed temperature, confining and pore-fluid pressure conditions without fluid flow, to couple the jacket with the granite core and to equilibrate sample with the experimental conditions. The differential fluid pressure gradient of $10 \mathrm{MPa}$ was then applied to initiate fluid flow across the core sample. The volume of fluid which passed through the sample was recorded continuously by the downstream metering pump. From this recorded volume, the flow rate $(Q)$ was calculated for each day of the experiment and at each significant change of the volume over time. Permeability $\left(k\right.$ in $\left.\mathrm{m}^{2}\right)$ was then calculated using Darcy's law and assuming a steady state flow:

$$
k=\frac{\mu L Q}{A \Delta P}
$$

where $Q\left(\mathrm{~m}^{3} \cdot \mathrm{s}^{-1}\right)$ is the flow rate across the sample, $\mu$ is the fluid viscosity under the experimental conditions $\left(6.7 \times 10^{-5} \mathrm{~Pa} . \mathrm{s}\right), L(\mathrm{~m})$ and $A\left(\mathrm{~m}^{2}\right)$ are, respectively, the length and cross-sectional area of the core sample, and $\Delta P$ $(\mathrm{Pa})$ is the imposed differential fluid pressure across the core sample $\left(P_{\text {up }}-P_{\text {down }}\right)$.

At the end of the experiment, the sample core was recovered and a polished thin section was prepared to study the alteration products and microtextures produced during the experiment using the analytical procedure described in Section 3.2.

3.5. Porosity and Density Measurements. The connected water porosity $(\varphi)$ and the matrix density of samples were determined using the double-weight water saturation (or imbibition) method at the laboratory of the BRGM (French Geological Survey). Before measurements, samples were cleaned and dried in a vacuum for at least $24 \mathrm{hr}$. Dry samples were weighed $\left(m_{\mathrm{d}}\right)$ and were then submerged for $24 \mathrm{hr}$ to ensure total saturation of the pores. After the full saturation of samples, the weight of the submerged samples $\left(m_{\mathrm{b}}\right)$ was determined by hydrostatic weighing. The weight of the saturated samples $\left(\mathrm{m}_{w}\right)$ was then determined after excess water was removed from the sample's surfaces. For each sample, $\varphi$ was calculated from

$$
\varphi(\%)=100 \times \frac{m_{\mathrm{w}}-m_{\mathrm{d}}}{m_{\mathrm{w}}-m_{\mathrm{b}}}
$$

and the matrix density $\left(\rho_{\mathrm{s}}\right)$ of samples was determined from the following expression:

$$
\rho_{\mathrm{s}}=\frac{m_{\mathrm{d}}}{m_{\mathrm{d}}-m_{\mathrm{b}}}
$$

This method provides good accuracy with precisions of $\pm 0.01{\mathrm{~g} . \mathrm{cm}^{-3}}$ for the density and $\pm 0.02 \%$ for the connected porosity.
3.6. Permeability Measurements at Hydrothermal Conditions. The permeability of natural samples collected at Panasqueira was measured in an internally heated Paterson apparatus equipped with a pore-fluid pressure system enabling measurement of the permeability under realistic temperature and pressure conditions [48-50]. This apparatus allows independent control of the argon confining pressure $\left(P_{c}\right)$, the temperature, and the pore-fluid pressure $\left(P_{\mathrm{f}}\right)$ and can be configured to deform samples both coaxially (compression) and noncoaxially (torsion) [51] (ESM 1).

Six cylindrical samples $(15 \mathrm{~mm}$ diameter, $35 \mathrm{~mm}$ in length) were prepared from rock specimens representative of different levels of greisenization, for which the connected porosity and density had been previously measured. Pore-fluid pressure and core samples were separated from the confining medium by a copper jacket, whose ductile nature ensures a complete sealing between the sample's sides and the jacket.

Based on hydrothermal conditions estimated from fluid inclusion studies performed on greisen systems worldwide and on the Panasqueira deposit, we imposed a temperature of $400^{\circ} \mathrm{C}$, a confining pressure of $100 \mathrm{MPa}$, and a pore-fluid pressure of $50 \mathrm{MPa}$ so as to determine the permeability at realistic and representative conditions for greisen systems. In all experiments, the procedure consisted of first raising $P_{\mathrm{c}}$ up to the target level of $100 \mathrm{MPa}$. The temperature was then raised to $400^{\circ} \mathrm{C} ; P_{\mathrm{c}}$ and $P_{\mathrm{f}}$ were adjusted to remain fixed at the conditions initially selected. Once the experimental conditions were stabilized, permeability was measured with deionized water as pore-fluid using the steady-state flow method for a Darcian flow (1). In all experiments, $\Delta P$ was fixed at $5 \mathrm{MPa}$, representing approximately $10 \%$ of the total pore-fluid pressure. For this purpose, the upstream pressure $\left(P_{\text {up }}\right)$ was automatically kept at $50 \mathrm{MPa}$ using a servo-controlled volumometer, while the downstream pressure $\left(P_{\text {down }}\right)$ was maintained at $45 \mathrm{MPa}$ by a micrometering needle valve. The volumometer that imposes $P_{\text {up }}$ was also used to measure the volume of fluid that flowed through the sample over the experimental period, enabling to calculate $Q$ by linear regression $(\mathrm{dV} / \mathrm{dt}$ ) (for more information in the electronic supplementary materials, see ESM 1).

\section{Greisenization Reactions and Microtextural Evolution}

4.1. Least Altered Two-Mica Granite: Mineralogical and Textural Characteristics. The mineralogical and microtextural characteristics of the least altered two-mica Panasqueira granite are displayed in Figure 4 (more photomicrographs are presented in electronic supplementary materials ESM 2). This granite exhibits a porphyritic texture marked by a lack of visible pores (Figure 4(a)).

K-feldspar forms large euhedral phenocryst (up to several centimeters) and small grains in the rock matrix (Figures 4(a)-4(d)). The K-feldspar may display perthitic texture resulting from the exsolution of albite lamellae, and poikilitic textures comprising numerous inclusions of quartz, albite, biotite, and apatite (Figures $4(\mathrm{~b})$ and 4(c)). In CL 


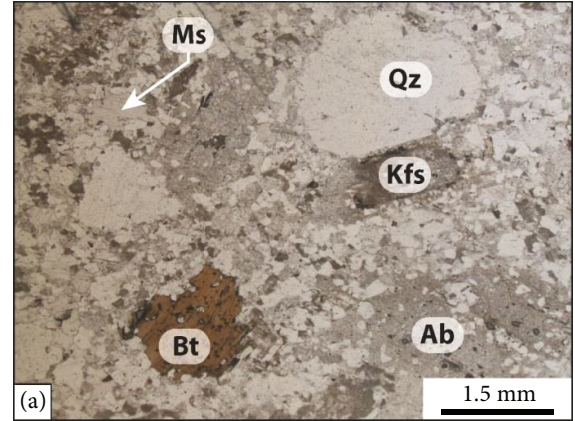

(a)

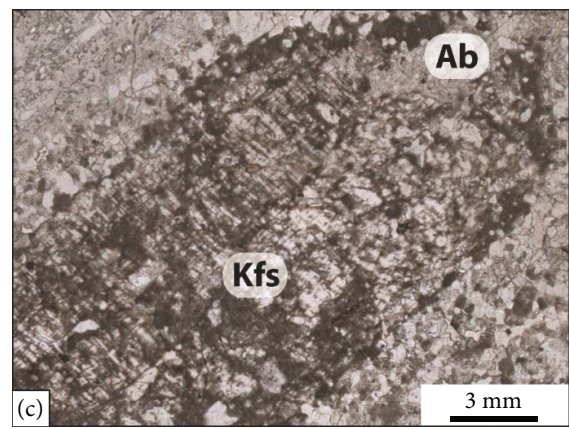

(c)

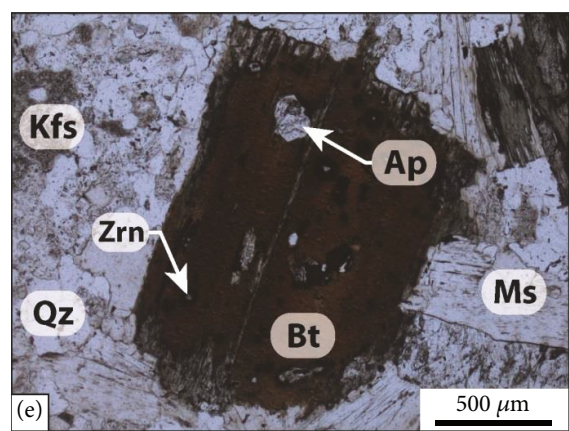

(e)

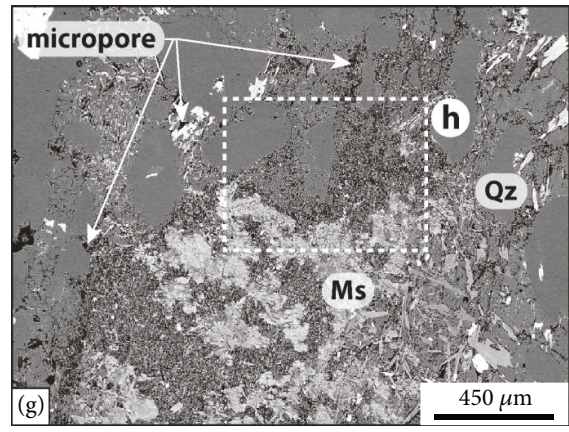

(g)

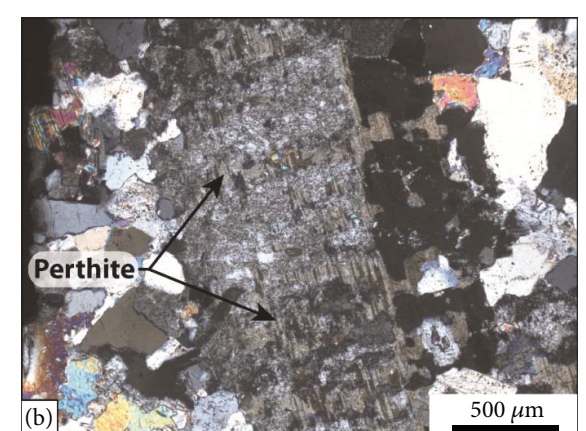

(b)

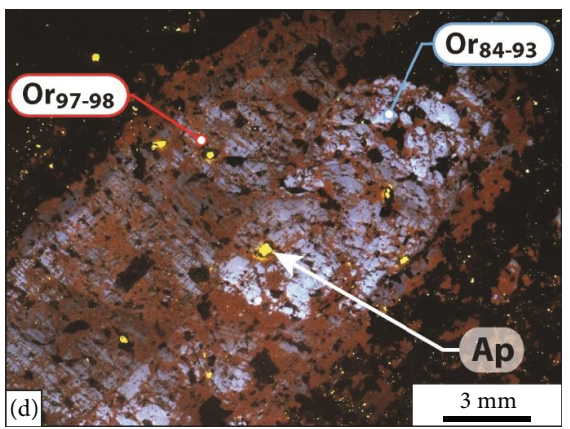

(d)

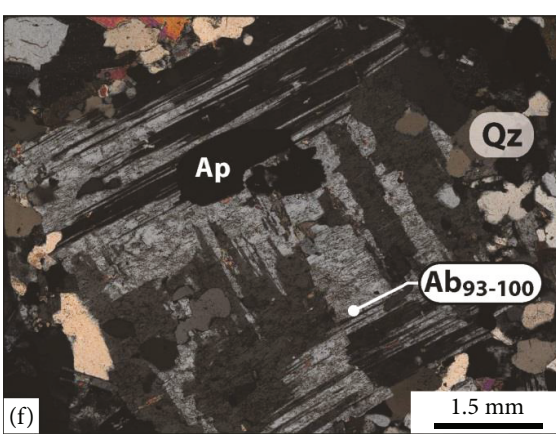

(f)

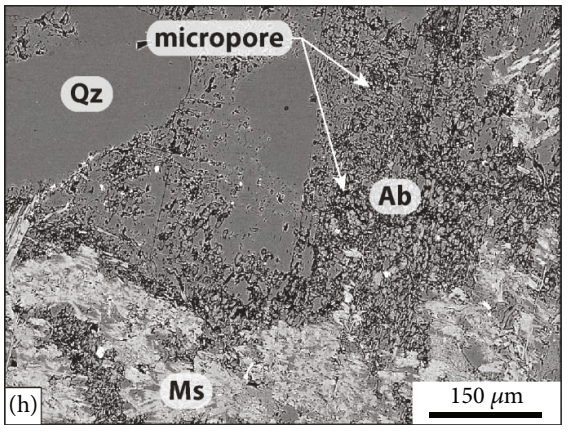

(h)

Figure 4: Mineralogical and microtextural characteristics of the two-mica Panasqueira granite. (a) Photomicrograph displaying a general view of the two-mica granite (transmitted light). (b) Photomicrograph of matrix K-feldspars exhibiting typical perthitic textures (polarized transmitted light). (c) Phenocryst of K-feldspar marked by poikilitic textures (inclusions of biotite, albite, and apatite) (transmitted light). (d) Cathodoluminescence image of the same k-feldspar phenocryst displayed in (c). This grain exhibits blue and red luminescent zones corresponding to different chemical compositions (indicated on image) that are related to K-metasomatism of primary magmatic alkali feldspars (blue luminescent zones). (e) Large euhedral flake of biotite containing numerous zircon and apatite inclusions (transmitted light). (f) Phenocryst of albite with quartz and apatite inclusions. The chemical composition of albite is indicated on the photomicrograph (polarized transmitted light). (g and h) SEM-BSE images of albite displaying typical pitted textures marked by the occurrence of a dense network of micropores. Abbreviations from Whitney and Evans [45]. Ab: Albite; Ap: apatite; Bt: biotite; Kfs: K-feldspar; Ms: muscovite; Or: orthoclase; Qz: quartz; Zrn: zircon. 
imaging, K-feldspar is marked by a complex texture with prominant blue and red luminescent zones (Figure $4(\mathrm{~d})$ ). Microprobe analyses (EPMA) of these zones indicate that the blue luminescent feldspars are characterized by compositions ranging between Or84 and Or93, while the red zones are characterized by compositions ranging between Or97 and Or98 (Figure 4(d)) (complete analyses of feldspars are provided in electronic supplementary materials ESM 3). Evidently, the original magmatic alkali feldspars (blue luminescent zones) were affected by K-metasomatism, during which they were converted to nearly pure orthoclase (red luminescent zones). These observations are consistent with numerous studies describing the relationships between the cathodoluminescence characteristics of alkali feldspars and the level of $\mathrm{K}$-metasomatism induced by hydrothermal fluids [52-55]. According to Lee et al. [53], the blue CL color could be related to the presence of $\mathrm{Ti}$ in primary magmatic alkali feldspar, while the red CL color is inferred to be activated by the presence of $\mathrm{Fe}^{3+}$ in the metasomatised part of K-feldspar.

Biotite is common, forming large subeuhedral flakes (up to $2 \mathrm{~mm}$ ) containing numerous inclusions of accessory minerals such as apatite, zircon (outlined by the occurrence of disintegration halos), monazite, rutile, and ilmenite (Figure $4(\mathrm{e})$ ). The occurrences of biotite inclusions in K-feldspar suggest that the crystallization of biotite precedes the crystallization of K-feldspar.

Albite is mainly present as numerous small euhedral grains and also as large phenocrysts with sizes ranging from 1 to $5 \mathrm{~mm}$ (Figures 4(a) and 4(f)). This albite is characterized by a typical polysynthetic twining texture and by poikilitic texture marked by inclusions of quartz and apatite (Figure 4(f)). Microprobe analyses show that the plagioclase has nearly pure albite compositions (Ab93 to Ab100) (Figure 4(f)). These compositions suggest that primary magmatic plagioclase was completely replaced by albite during an early albitization event commonly observed in greisen systems, which predates greisenization $[6,56]$. This pseudomorphic replacement of plagioclase is accompanied by the development of a pervasive network of micropores (pitted textures) within the albite grains (Figures $4(\mathrm{~g})$ and $4(\mathrm{~h})$ ). This porosity generation is commonly described from magmatic-hydrothermal systems affected by K-metasomatism and albitization [9-11, 57-59] and results from coupled dissolution-precipitation reactions (CDP) discussed in detail by Putnis [26], Engvik et al. [60], and Putnis and Austrheim [27]. The development of pitted textures during albitization could contribute to the enhancement of subsequent greisenization by promoting pervasive fluid flow through feldspars.

These textural and mineralogical observations provide evidence that greisenization of the two-mica Panasqueira granite was preceded by high-temperature alkali metasomatism (K-metasomatism and albitization), during which primary magmatic plagioclase and alkali feldspars were, respectively, converted into nearly pure albite and orthoclase. Consequently, samples used as reference for the initial rock properties before greisenization are referred to as the "least altered granite" in the following sections.
4.2. Mineral Replacement Textures. Partially greisenized facies enable observation of the progressive breakdown of albite (Figure 5(a)), K-feldspar (Figure 5(b)), and biotite (Figure 5(c)) induced by the greisen alteration.

K-feldspars and albite are partially and unevenly replaced by a fine-grained quartz-muscovite assemblage. In the most altered portions of feldspars, the small flakes of muscovite have progressively recrystallized and become agglomerated to form large flakes. As illustrated by $\mathrm{Na}$ and $\mathrm{K}$ mapping, small portions of the parental feldspars have survived along grain edges and may still occur as intergrowth between muscovite crystals.

Alteration of biotite creates coronitic textures composed of irregular residual grains of biotite surrounded by neoformed muscovite. The replacement of biotite by muscovite can also occur along the cleavage planes of biotite that were probable pathways for fluids. The presence of ilmenite disseminated throughout the neoformed muscovite indicates that $\mathrm{Fe}$ and $\mathrm{Ti}$ released by the biotite alteration have crystallized to form these oxide minerals (Figure 5(c)).

These alteration textures show that greisenization involves CDP mechanisms, during which primary magmatic minerals were gradually dissolved and simultaneously replaced by newly crystallized muscovite and quartz. The micropore network observed in altered sections of $\mathrm{K}$ feldspars and albite developed during the early alkali metasomatism could promote the circulation of greisenizing fluids through feldspars and enhance their replacement by muscovite during the greisenization.

\subsection{Microtextural Evolution Related to the Greisenization.} The microtextural evolution induced by the greisenization is displayed from SEM-BSE images in Figure 6 (more SEM-BSE images are displayed in electronic supplementary materials ESM 4). As evidenced in the SEM-BSE images, the greisenization is accompanied by the development of a porous texture. In greisenized granite, albite is still present in the rock matrix and the porosity comprises a combination of pores and microcracks connecting individual pores. Spaces between muscovite grains provide a network of intergranular pores (Figure 6(a)). These pores are unevenly distributed in the rock matrix and organized into pockets (Figures 6(a) and $6(\mathrm{~b})$ ). This heterogeneous distribution may result from the uneven distribution of feldspars from which pores could be formed during the replacement reactions.

As in greisenized granite, the porosity within the greisen comprises a combination of pores and microcracks preferentially opened in quartz (Figures 6(c) and 6(d)). These microcracks seem to connect the isolated pores unevenly distributed throughout the rock matrix. The intergranular spaces between muscovite represent a large part of the porosity (Figure 6(d)). The abundance and size of the pores seem to increase between greisenized granite and the most altered greisen, with a pore size ranging from few microns to tens of microns in greisenized granite and from several hundred micrometers to several millimeters in greisen. In the most porous facies, porosity forms a dense intergranular network, in which hydrothermal minerals such as euhedral apatite have crystallized (Figures 6(d) and 6(f)). Large voids (up to 

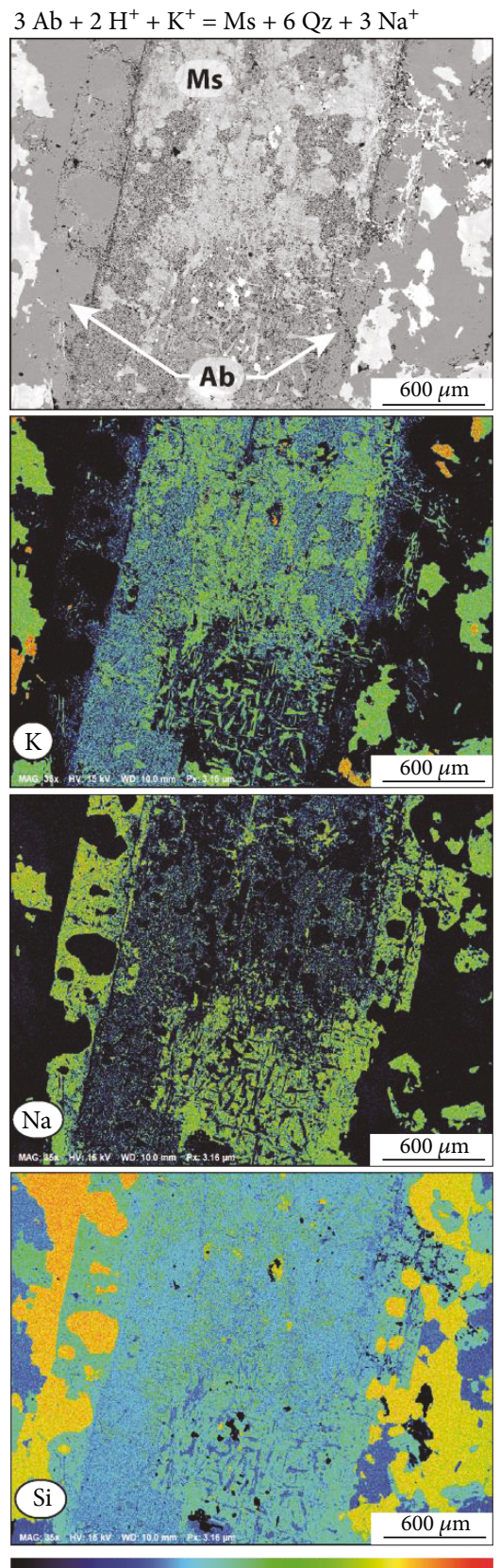

Low

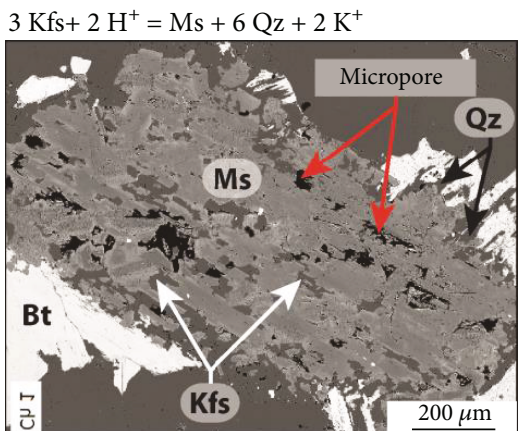

$3 \mathrm{Bt}+2 \mathrm{H}^{+}=$

$\mathrm{Ms}+6 \mathrm{Qz}+\mathrm{Fe}-\mathrm{Ti}$ Oxide $+2 \mathrm{~K}^{+}+3 \mathrm{H}_{2}$
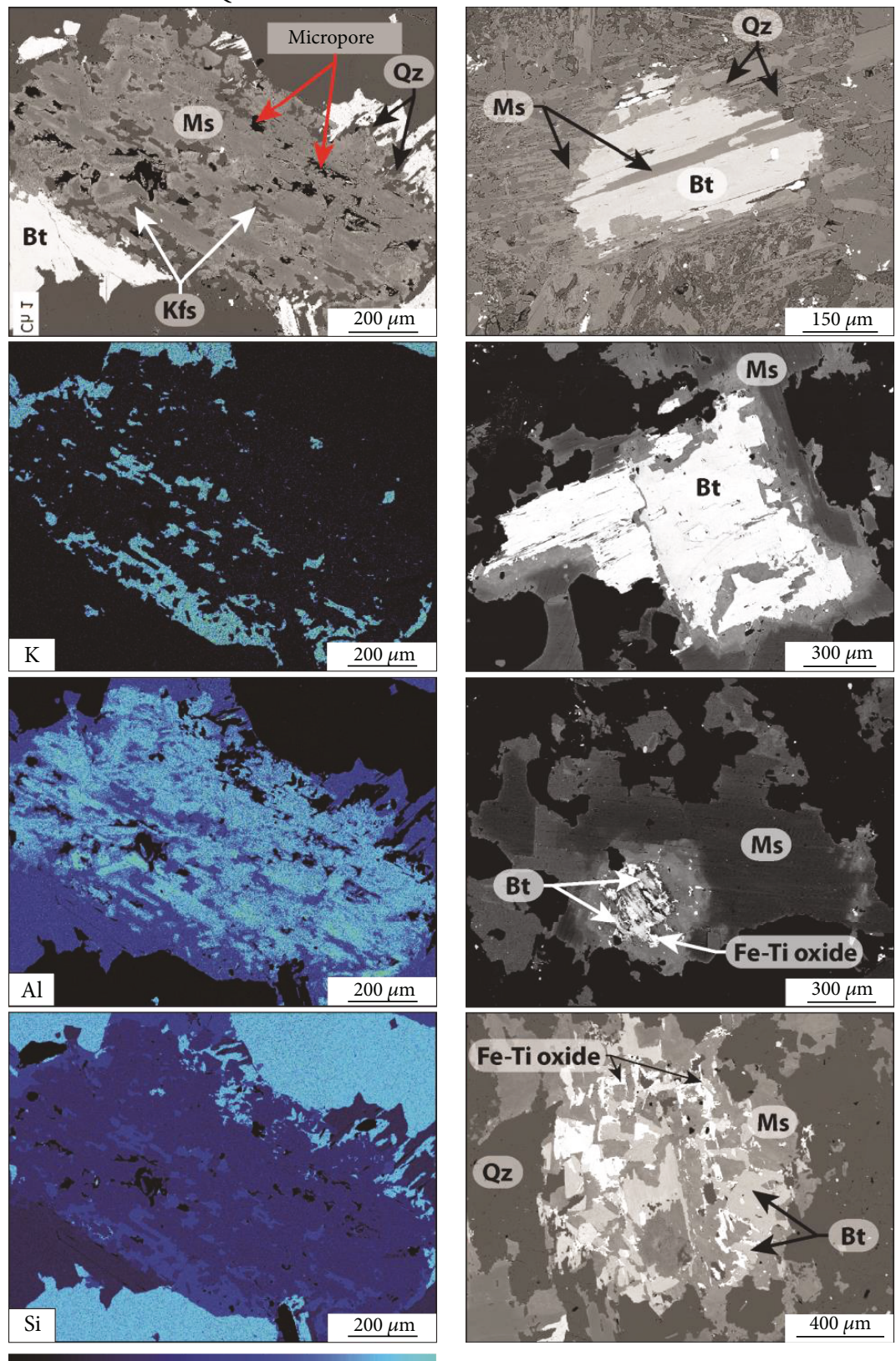

Low

High

(b)

(c)

FIGURE 5: SEM microphotographs and element mapping of Na, K, and Al showing the replacement textures of (a) albite, (b) K-feldspar, and (c) biotite involved during the greisen alteration. Note the development of microporosity in the altered sections of K-feldspar and albite. Abbreviations from Whitney and Evans [45]. Ab: albite; Bt: biotite; Kfs: k-feldspar; Ms: muscovite; Qz: quartz.

$5 \mathrm{~mm}$ ) can also be observed in greisen and show the development of porosity during greisenization (Figure 6(e)). These voids are commonly fringed by euhedral quartz indicating that adjacent crystals were growing into open space.

Muscovite composing greisen forms large euhedral flakes characterized by well-developed growth zoning marked by dark cores and light rims in SEM-BSE images (Figures 6(a) and 6(f)). These zonings correspond to core-to-rim enrichment in Fe and core-to-rim depletion in $\mathrm{Al}$ (Figures 6(g) and 6(h)). This chemical and textural zoning can be interpreted as hydrothermal overgrowths on primary magmatic muscovite during greisenization. This zoning pattern has already been described in ongonites (Mongolia) [10] and in the hydrothermally altered Sn-bearing granite of Ervedosa (northern Portugal) [61]. According to these studies, zoning observed in muscovite results from fluid-rock 


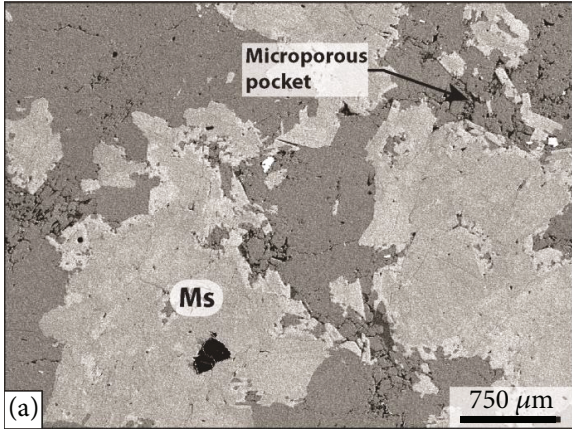

(a)

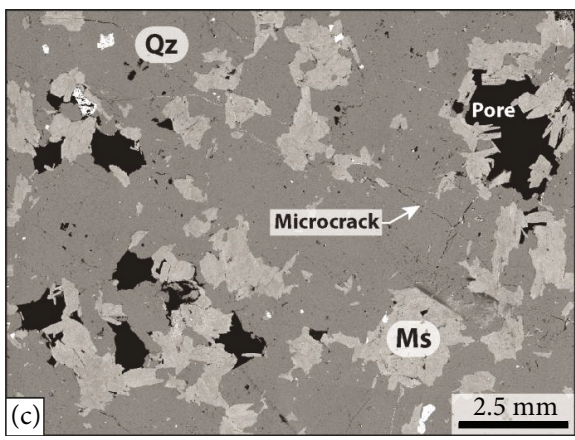

(c)

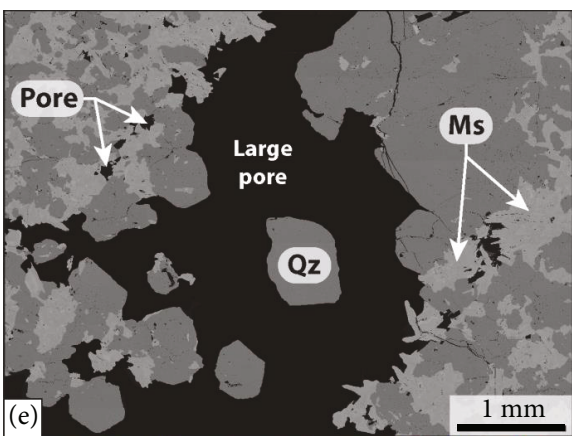

(e)

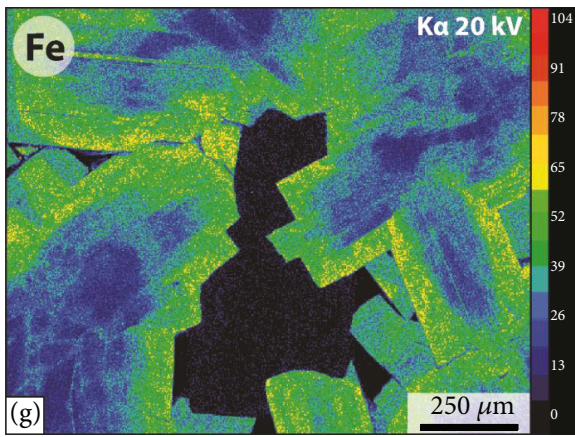

(g)

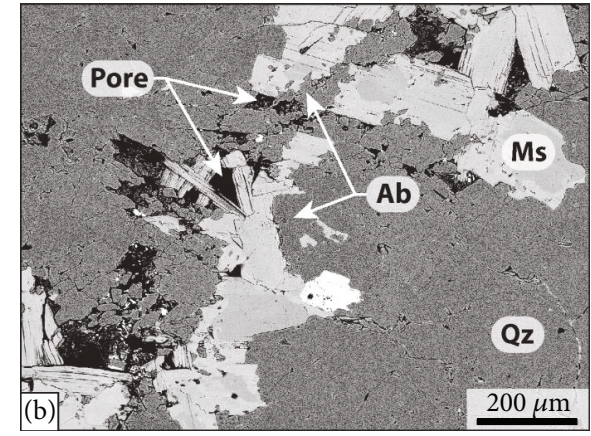

(b)

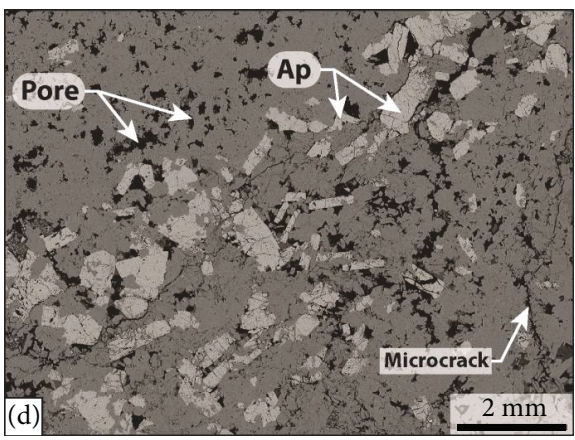

(d)

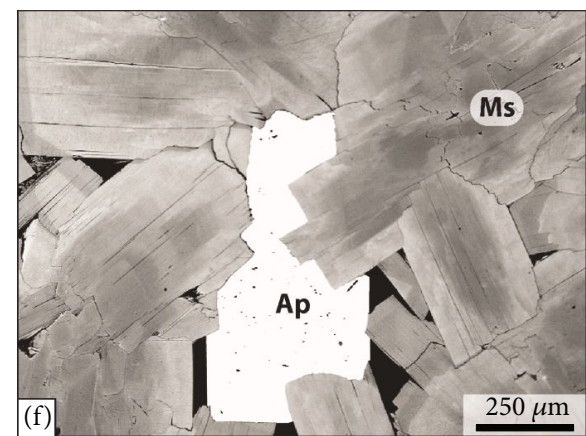

(f)

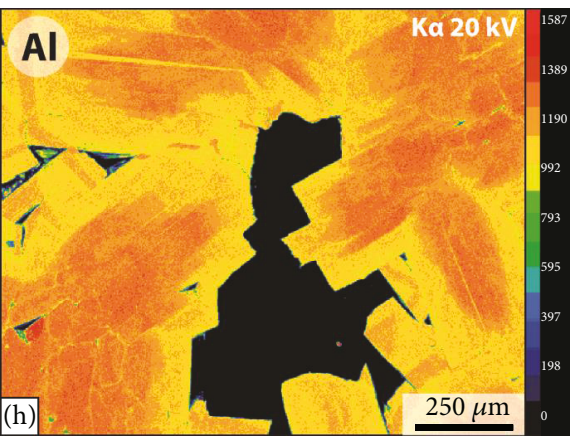

(h)

FIgURE 6: SEM-BSE images displaying the microtextural evolution induced by the greisenization of the Panasqueira granite. (a) Porous texture in a greisenized granite sample showing the heterogeneous distribution of the porosity. A microporous pocket and a microcrack are labeled. (b) Enlargement of a microporous pocket showing the intergranular porosity corresponding to spaces around muscovite grains. (c) Porous texture in greisen showing large pores corresponding to spaces around muscovite grains (this section was made from the sample shown in Figure 2(b), 1). (d) Porous greisen, in which a large amount of hydrothermal apatite has crystallized during the late hydrothermal stages. (e) Large void space fringed by euhedral quartz, which has crystallized from the pore's edge. (f) SEM-BSE image showing hydrothermal overgrowth of muscovite forming greisen and pore space partially infilled by hydrothermal apatite. (g) Fe and (h) Al chemical maps prepared from the section shown in (f). Abbreviations from Whitney and Evans [45]. Ab: albite; Ap: apatite; Ms: muscovite; Qz: quartz. 


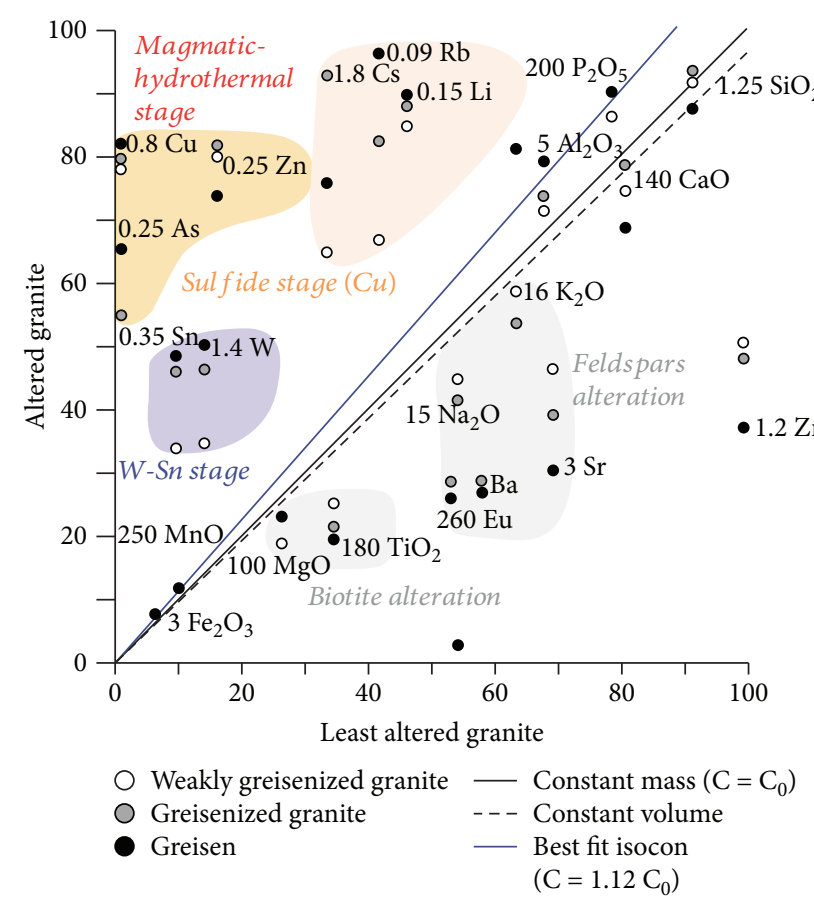

Figure 7: Isocon diagram comparing the chemical composition of the least altered granite and the Panasqueira greisen. Granite composition is an average of 5 analyses. Oxide analyses are in wt $\%$ and trace elements in ppm; values are scaled with the factors indicated for each element. The best fit isocon (blue line) defined from $\mathrm{P}_{2} \mathrm{O}_{5}, \mathrm{Al}_{2} \mathrm{O}_{3}, \mathrm{MnO}$, and $\mathrm{Fe}_{2} \mathrm{O}_{3}$ is compatible with an immobile alumina during the greisen alteration. This best fit is characterized by a slope of 1.12 corresponding to a volume decrease of about $12.4 \%$. For comparison, an isocon based on hypotheses of constant mass (black line) and constant volume (dashed line) is also plotted.

interactions during the mineralization event. As shown by chemical mapping, these hydrothermal overgrowths on muscovite have grown preferentially in the open pore spaces developed during the greisenization.

The extensive development of pores and micropores in greisen may be a response to the mineralogical transformation induced by the replacement of primary minerals in the Panasqueira granite during greisenization. This suggests that replacement reactions related to the greisenization are probably associated with a volume decrease of the solid phase that may constitute an efficient mechanism for enhancing porosity.

4.4. Chemical Changes and Chemical Alteration Index (AI). The mineralogical transformations described above cause significant changes in the whole rock composition. To account for element mobility during the greisen alteration, the whole rock composition of samples representative of different degrees of greisenization is reported as a function of the least altered granite composition in an isocon diagram (Figure 7) [62,63]. We define the best fit isocon (blue line in Figure 7) for the most altered granite (greisen) by using the least scattered of all elements, $\mathrm{Al}, \mathrm{P}, \mathrm{Mn}$, and $\mathrm{Fe}$, and assuming that these elements were immobile during the greisenization. The aluminum immobility is a reasonable assumption considering that feldspars are replaced by muscovite which is a major aluminum-bearing-mineral. Figure 7 shows that the greisen alteration encompasses a complex history leading to a progressive mass loss in $\mathrm{Na}$, $\mathrm{K}, \mathrm{Si}, \mathrm{Ca}, \mathrm{Sr}, \mathrm{Ba}, \mathrm{Eu}, \mathrm{Mg}$, and $\mathrm{Ti}$ and mass gain in $\mathrm{Li}, \mathrm{Rb}$, $\mathrm{Cs}, \mathrm{Sn}, \mathrm{W}, \mathrm{Cu}, \mathrm{Zn}$, and As.

This evolution is consistent with the breakdown of feldspar and biotite and the new growth of a large amount of muscovite during the greisen alteration. Destructions of $\mathrm{K}$-feldspar and albite have, respectively, released $\mathrm{K}, \mathrm{Ba}$ and $\mathrm{Na}, \mathrm{K}, \mathrm{Ba}, \mathrm{Sr}$, and $\mathrm{Eu}$ into the fluids, while the formation of muscovite was probably responsible of the enrichment in $\mathrm{Li}, \mathrm{Rb}$, and $\mathrm{Cs}$, all these elements having a strong affinity with muscovite. This enrichment in granitophile elements ( $\mathrm{Li}, \mathrm{Rb}$, and $\mathrm{Cs}$ ) is also probably related to the ingress of orthomagmatic fluids, which are commonly enriched in these elements.

Although Ti-rich oxides were formed during the transformation of biotite into muscovite, the mass loss in Ti suggests that the $\mathrm{Ti}$ constituting biotite was partially released into the fluids. The significant mass gain in $\mathrm{Sn}, \mathrm{W}$ and $\mathrm{Cu}$, $\mathrm{Zn}$, and As highlights that greisen facies have also recorded the various mineralization stages occurring in the vein system at Panasqueira. The presence of a disseminated mineralization of cassiterite and sulfides in greisen is consistent with these mass gains and suggests that the various mineralized fluids flowed through greisen during the time that the mineralization stages occurred.

According to the best-fit isocon, the greisenization of the Panasqueira granite is characterized by an overall volume loss of $\sim 12.4 \%$, which is consistent with the porosity developed in the greisen facies. However, alteration leading to the formation of greisen (most altered granite) was likely progressive and encompassed many steps, whose effects were cumulated over the entire hydrothermal activity of Panasqueira. Accordingly, the overall volume loss estimated from the best-fit isocon could be slightly overestimated.

Based on the assumption that the whole-rock compositional change in the greisen facies is controlled by the degree of alteration, we can define a chemical alteration index (AI) from the changes in $\mathrm{Al}, \mathrm{Na}$, and $\mathrm{K}$ concentrations (in wt\%):

$$
\mathrm{AI}=100 \times \frac{\mathrm{Al}_{2} \mathrm{O}_{3}}{\mathrm{Al}_{2} \mathrm{O}_{3}+\mathrm{CaO}+\mathrm{Na}_{2} \mathrm{O}+\mathrm{K}_{2} \mathrm{O}} .
$$

This chemical alteration index, which increases with greisen alteration, is based on the ratio of immobile (Al) to mobile $(\mathrm{Ca}, \mathrm{Na}$, and $\mathrm{K})$ elements during greisen alteration and reflects the progressive breakdown of feldspars. This index provides a useful approach for estimating the degree of greisen alteration of the samples investigated and was used to follow the evolution of the rock's petrophysical properties as a function of the level of greisenization. Moreover, this chemical alteration index is commonly applied in the literature to characterize the degree of alteration in diverse geological environments involving the breakdown of feldspars [64-66]. 
TABLE 1: Molar volume changes $(\Delta V)$ induced by the replacement reactions related to the greisen alteration of the least altered Panasqueira granite. $\Delta V\left(\mathrm{~cm}^{3} / \mathrm{mol}\right)$ are calculated at $400^{\circ} \mathrm{C}$ and $100 \mathrm{MPa}$ using the thermodynamic database SUPCRTBL. $\Delta V$ (\%) is the molar volume change relative to the molar volume of the reactant minerals.

\begin{tabular}{|c|c|c|c|}
\hline \multicolumn{2}{|c|}{ Replacement reaction } & \multirow{2}{*}{$\frac{\Delta V\left(\mathrm{~cm}^{3} / \mathrm{mol}\right)}{-35.3}$} & \multirow{2}{*}{$\frac{\Delta V(\%)}{-10.8}$} \\
\hline (R1) & $3 \mathrm{KAlSi}_{3} \mathrm{O}_{8}+2 \mathrm{H}_{(a q)}^{+}=\mathrm{KAl}_{3} \mathrm{Si}_{3} \mathrm{O}_{10}(\mathrm{OH})_{2}+6 \mathrm{SiO}_{2}+2 \mathrm{~K}_{(a q)}^{+}$ & & \\
\hline$(\mathrm{R} 2)$ & $3 \mathrm{NaAlSi}_{3} \mathrm{O}_{8}+2 \mathrm{H}_{(\mathrm{aq})}^{+}+\mathrm{K}_{(\mathrm{aq})}^{+}=\mathrm{KAl}_{3} \mathrm{Si}_{3} \mathrm{O}_{10}(\mathrm{OH})_{2}+6 \mathrm{SiO}_{2}+3 \mathrm{Na}_{(\mathrm{aq})}^{+}$ & -44.4 & -14.3 \\
\hline (R3) & $3 \mathrm{KFe}_{3} \mathrm{AlSi}_{3} \mathrm{O}_{10}(\mathrm{OH})_{2}+2 \mathrm{H}_{(\mathrm{aq})}^{+}=\mathrm{KAl}_{3} \mathrm{Si}_{3} \mathrm{O}_{10}(\mathrm{OH})_{2}+6 \mathrm{SiO}_{2}+3 \mathrm{Fe}_{3} \mathrm{O}_{4}+2 \mathrm{~K}_{(\mathrm{aq})}^{+}+3 \mathrm{H}_{2(\mathrm{aq})}$ & -38.1 & -8.2 \\
\hline
\end{tabular}

4.5. Mineral Replacement Reactions and Changes in Rock Volume. Based on the mineral replacement textures and the whole-rock geochemical changes related to the greisen alteration, replacement reactions involved during the greisenization may be written as summarized in Table 1. These reactions are based on the assumption that $\mathrm{Al}$ was immobile and conserved among the solid phases during the alteration. As previously mentioned, primary magmatic feldspars had already been metasomatised as to form albite and orthoclase, so the reactions were defined considering feldspars with pure albite and orthoclase compositions. During these reactions, a large amount of $\mathrm{H}^{+}$was consumed from fluids, whereas $\mathrm{Na}^{+}$ and $\mathrm{K}^{+}$were released into the fluids, as expected from the whole-rock compositional changes described earlier. This is consistent with the extreme leaching of alkali cations by acidic fluids commonly observed in greisen systems $[5,6]$.

The relative volume change $\Delta V(\%)$ induced by these reactions can be calculated from the stoichiometric coefficients and molar volumes of the solid phases [25]. Calculations were performed using the molar volumes of minerals in the thermodynamic database SUPCRTBL [46, 47] under realistic hydrothermal conditions $\left(400^{\circ} \mathrm{C}\right.$ and $\left.100 \mathrm{MPa}\right)$ [67] and applying the following expression:

$$
\Delta V(\%)=100 \cdot\left(\frac{\sum x_{i}^{\mathrm{p}} \cdot V_{i}-\Sigma x_{i}^{\mathrm{r}} \cdot V_{i}}{\sum x_{i}^{\mathrm{r}} \cdot V_{i}}\right)
$$

with $x_{i}^{\mathrm{p}}$ and $x_{i}^{\mathrm{r}}$ the stoichiometric coefficients of the product and reactant minerals and $V_{i}\left(\mathrm{~cm}^{3} / \mathrm{mol}\right)$ the molar volumes of associated minerals. Volume changes induced by each alteration reaction are summarized in Table 1.

Reactions R1, R2, and R3 are characterized by volume decreases of $10.8 \%, 14.3 \%$, and $8.2 \%$, respectively, compatible with the development of porosity observed in facies of greisenized granite and greisen (Figure 6). This suggests that open spaces were created during these replacement reactions and hence that porosity could increase during the greisenization. In the case of the Panasqueira greisen, feldspars and biotite are completely replaced by muscovite and the replacement reactions may therefore be considered as total. Consequently, the porosity potentially developed during these reactions can be estimated assuming volumetric mineral abundances of $17 \%$ for $\mathrm{K}$-feldspar, $28 \%$ for albite, and $8 \%$ for biotite (mineral abundances estimated from XRD data in the electronic supplementary materials ESM 5). In light of this estimation, the process of mineral replacement could be accompanied by a porosity increase of $\sim 6.2 \%$, which is

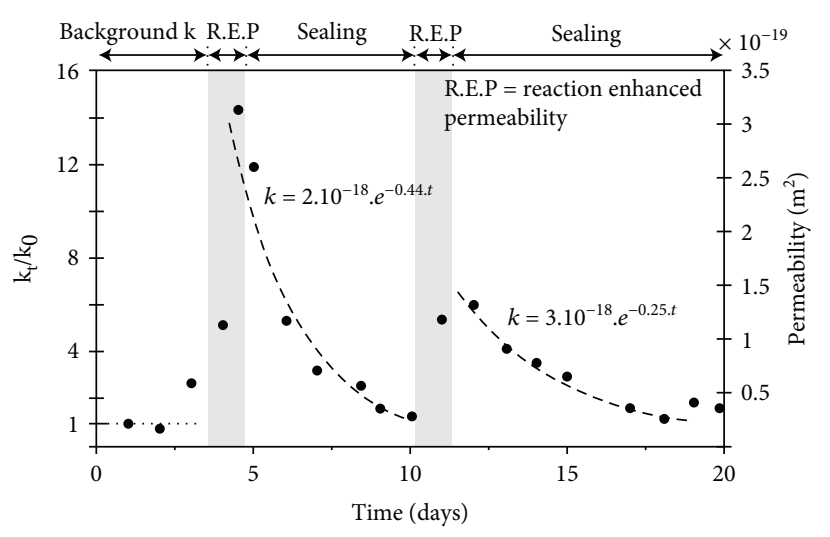

Figure 8: Evolution of permeability over time during the greisenization experiment. This time evolution depicts cycles of permeability increase followed by stages of gradual decrease that may, respectively, be attributed to porosity generation during the replacement reactions and sealing by closing of the neoformed pathways. The stages of permeability decrease fit with exponential functions commonly observed in experimental studies.

consistent with the overall volume decrease predicted by the isocon diagram. This predicted porosity increase is compatible with the development of the porous textures observed in greisen and greisenized facies.

\section{Relationships between Textural Evolution and Permeability during Greisenization}

Replacement reactions involved during the greisenization result in a volume decrease of the solid phases that could induce porosity generation in greisenized facies. This raises the question of the effect of these replacement reactions on rock permeability. In this section, we discuss the results obtained from the greisenization experiment to determine whether alteration reactions can generate new fluid pathways by the development and maintenance of neoformed porosity at the start of the greisen alteration event.

5.1. Evolution of Permeability over Time during the Greisenization Experiment. The time evolution of permeability during the greisenization experiment is shown in Figure 8. The initial permeability of the unaltered granite is about $2.0 \times 10^{-20} \mathrm{~m}^{2}$, a value similar to the permeability values usually obtained in intact granite samples [22, 50, 68, 69]. The permeability changes measured over the experimental period are normalized to this initial permeability value. After three days of experiment, the permeability increases rapidly with 


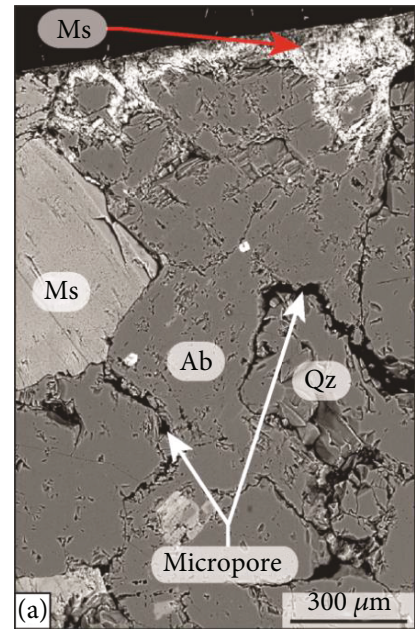

(a)

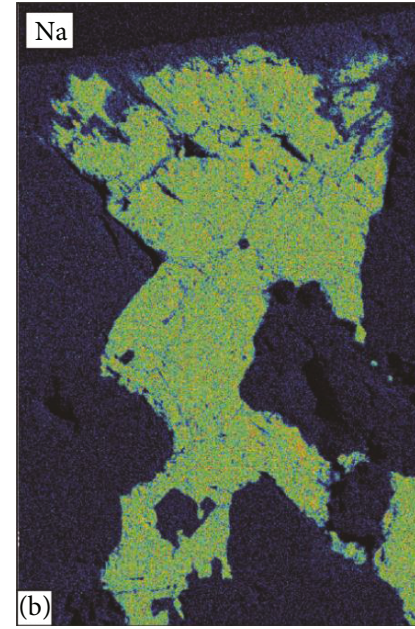

(b)

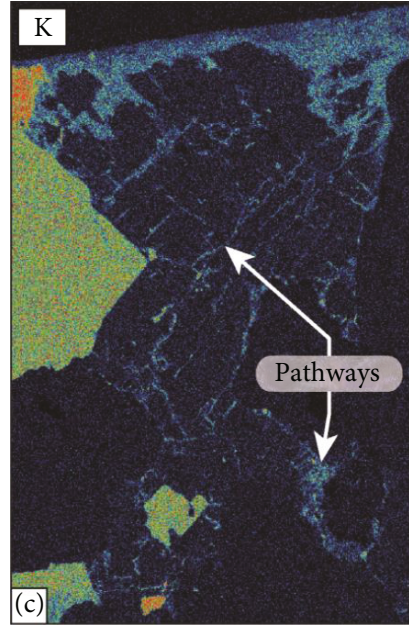

(c)

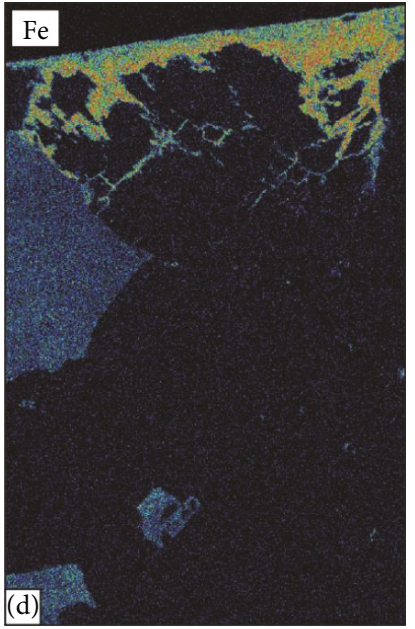

(d)

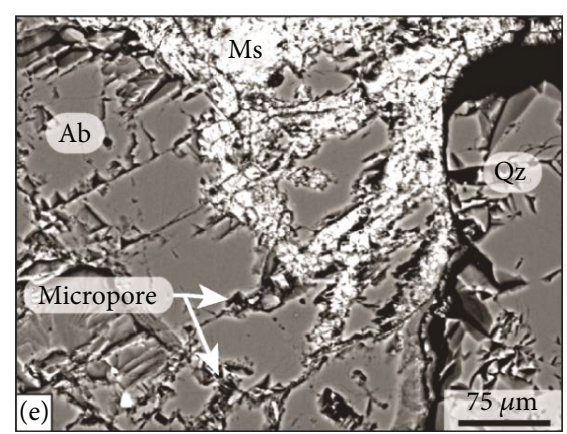

(e)

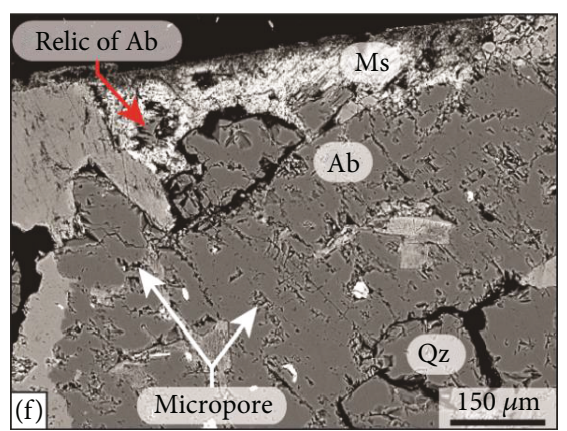

(f)

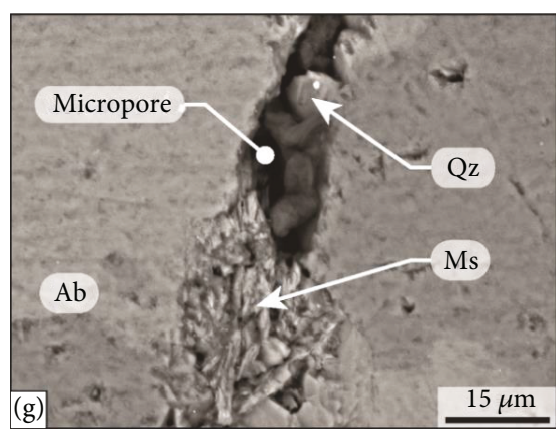

(g)

FIgURE 9: Texture of the alteration products obtained during the greisenization experiment. (a-d) SEM-BSE images and element maps showing the distribution of $\mathrm{Na}, \mathrm{K}$, and $\mathrm{Fe}$ in a partially altered part of the granite core. These maps display the pathways along which fluids have preferentially flowed and altered albite into muscovite during the experiment. (e) SEM photomicrograph showing the dissolution and enlargement of the pathway along the grain boundary between quartz and albite and the development of micropore along the cleavage planes of albite. (f) SEM photomicrograph showing the microporous texture of a partially altered albite. (g) Zoom on a micropore developed during the experiment that was partially coated by euhedral quartz and muscovite. Abbreviations from Whitney and Evans [45]. Ab: albite; Ms: muscovite; Qz: quartz.

a factor growth of 14 up to $3.0 \times 10^{-19} \mathrm{~m}^{2}$. Afterwards, the permeability decreases progressively for five days and returns to its initial value following an exponential law. Then, after eleven days of experiment, the permeability increases a second time up to $1.3 \times 10^{-19} \mathrm{~m}^{2}$ (factor growth of 6). This second increase is also followed by an exponential permeability decrease down to $3.3 \times 10^{-20} \mathrm{~m}^{2}$.

5.2. Replacement Products and Interpretation of the Permeability's Evolution. SEM photomicrographs and chemical maps of the alteration products and microtextures developed during the greisenization experiment are shown in Figure 9 (more SEM-BSE images are displayed in electronic supplementary materials ESM 6 and ESM 7). As evidenced by $\mathrm{Na}, \mathrm{K}$, and Fe chemical maps (Figures 9(b)-9(d)), alteration has progressed from the upper edge of the granite core in which relics of residual albite can be observed in the neoformed muscovite. During this alteration, feldspars (albite) were replaced by muscovite enriched in Fe compared to the primary muscovite constituting the initial granite. This replacement has occurred preferentially along the grain boundaries and cleavage planes that probably played the role of preferential pathways for elements dissolved in fluid. These interfaces have enhanced the fluid-mineral interactions and initiated the replacement reactions. SEM images show that the replacement of feldspar by muscovite is marked by the development of a microporous texture in altered products (Figures 9(e) and 9(f)). Partially altered sections of albite (Figure 9(f)) are characterized by the presence of numerous micropores that are partially fringed by muscovite and euhedral quartz (Figure $9(\mathrm{~g})$ ). This suggests that fluids have flowed through the newly formed porosity to promote further alteration.

The creation of porosity seen in the alteration products can be related to the molar volume decrease induced by coupled dissolution-precipitation (CDP) reactions involving the dissolution of albite and the precipitation of muscovite [12, 25-27]. These CDP reactions were mainly controlled by the $\mathrm{pH}$ of the fluid that has triggered and driven the dissolution of albite. This development of porosity in the reaction products has probably provided new fluid pathways that may explain the two permeability increases observed during the 
TABLE 2: Rock petrophysical properties measured in samples of granite, greisenized granite, and greisen from Panasqueira. AI corresponds to the chemical alteration index defined in Section 4.3.

\begin{tabular}{|c|c|c|c|c|c|c|}
\hline & Location & AI & $\begin{array}{c}\rho_{\mathrm{s}} \\
\left(\text { g.cm } \mathrm{cm}^{-3}\right)\end{array}$ & $\begin{array}{c}\phi \\
(\%)\end{array}$ & $k_{25 \circ \mathrm{C}}\left(\mathrm{m}^{2}\right)$ & $k_{400 \circ \mathrm{C}}\left(\mathrm{m}^{2}\right)$ \\
\hline \multicolumn{7}{|l|}{ Granite } \\
\hline E2 & SCB2 & 61.9 & 2.68 & 0.54 & $3.53 \times 10^{-20}$ & $1.89 \times 10^{-20}$ \\
\hline D3 & SCB2 & 62.2 & 2.66 & 0.59 & - & - \\
\hline D1 & SCB2 & 62.1 & 2.69 & 0.6 & - & - \\
\hline D2 & SCB2 & 64.3 & 2.69 & 0.70 & - & - \\
\hline D4 & SCB2 & 62.6 & 2.68 & 0.71 & - & $6.27 \times 10^{-20}$ \\
\hline \multicolumn{7}{|c|}{ Greisenized granite } \\
\hline $\mathrm{C} 1$ & SCB2 & 66.4 & 2.70 & 1.08 & $6.5 \times 10^{-19}$ & $2.20 \times 10^{-19}$ \\
\hline $\mathrm{O} 4$ & SCB2 & 66.1 & 2.72 & 0.99 & - & - \\
\hline P3D & Mine & 67.0 & 2.71 & 1.37 & - & - \\
\hline P3C & Mine & 68.1 & 2.76 & 1.8 & $4.45 \times 10^{-18}$ & $1.52 \times 10^{-18}$ \\
\hline P3E & Mine & 66.9 & 2.75 & 1.53 & - & - \\
\hline $\mathrm{O} 1$ & SCB2 & 68.6 & 2.72 & 1.64 & - & - \\
\hline $\mathrm{O} 3$ & SCB2 & 66.1 & 2.73 & 1.58 & - & - \\
\hline O5 & SCB2 & 70.3 & 2.73 & 3.26 & $5.36 \times 10^{-18}$ & $2.97 \times 10^{-18}$ \\
\hline P4-2 & Mine & 72.3 & 2.79 & 3.34 & - & - \\
\hline P4-3 & Mine & 69.8 & 2.73 & 2.04 & - & - \\
\hline P4-4 & Mine & 71.4 & 2.73 & 2.04 & - & - \\
\hline \multicolumn{7}{|l|}{ Greisen } \\
\hline $\mathrm{B} 2$ & SCB2 & 72.9 & 2.9 & 5.91 & $1.26 \times 10^{-17}$ & $1.24 \times 10^{-17}$ \\
\hline $\mathrm{B} 1$ & SCB2 & 72.8 & 2.87 & 5.86 & - & - \\
\hline P57-A & Mine & 73.9 & 2.93 & 8.97 & - & - \\
\hline \multicolumn{7}{|c|}{ Host rock (Beira schist) } \\
\hline A1 & SCB2 & - & - & - & - & $1.52 \times 10^{-20}$ \\
\hline
\end{tabular}

experiment (at 5 and 11 days). The permeability reductions observed after each permeability increases are characterized by the same type of reduction rate (exponential decrease) observed in experiments performed on fractured granite samples $[50,68,70]$. In these studies, the permeability decrease is commonly interpreted as the result of the gradual chemical equilibration of the fluid with the rock sample during fluid-rock interactions. This equilibration could lead to the fluid becoming saturated in product phases such as $\mathrm{SiO}_{2}$ that could induce the precipitation of quartz in the neoformed porosity, thereby triggering the sealing of the pathways and hence the permeability decrease observed in our experiment [71]. This suggests a potential competition between replacement reactions, which promote and enhance fluid flow by the generation of porosity, and the solubility of product phases released into fluids that could induce the sealing of fluid pathways by mineral precipitation [14, 25]. The cycles of permeability increase and reduction observed during our experiment may be interpreted as the results of the successive generation of pathways by alteration, and the closing of those pathways in response to the processes described above.

Thus, ultimately, this experiment suggests that greisen alteration is able to increase the permeability by the same order of magnitude as those observed during fracturing experiments by Tenthorey and Fitzgerald [50]. This emphasizes that replacement reactions related to greisenization are able to generate new pathways for fluids and that this mechanism can be as efficient as fracturing for improving fluid flow in granitic systems. However, this feedback between replacement reactions and permeability requires an efficient fluid renewal and element transport with high water/rock ratios, so as to keep open the neoformed pathways and to limit the process of sealing caused by the saturation and precipitation of product phases such as $\mathrm{SiO}_{2}$.

\section{Effects of the Greisenization on Rock Petrophysical Properties}

The replacement reactions related to the greisen alteration may generate porosity and enhance permeability. In the following, we present the results of petrophysical measurements carried out on natural samples representative of various degrees of greisenization to determine (i) to what extent the porosity and permeability can increase during greisen alteration, (ii) relationships between the evolution of porosity and permeability and the rock alteration index (AI), and (iii) the role of mineral replacement on changes in the rock's petrophysical properties.

6.1. Evolution of Density, Porosity, and Permeability during Greisen Alteration. The evolution of rock matrix density, connected porosity, and permeability is summarized in Table 2 and plotted as a function of the chemical alteration index (AI) in Figure 10. Permeabilities measured at ambient conditions $\left(\sim 25^{\circ} \mathrm{C}\right)$ are also included in Figure 10 (c) to show the slight effect of room temperature on permeability measurements. The unaltered granite is characterized by a matrix density ranging from 2.66 to $2.69 \mathrm{~g} . \mathrm{cm}^{-3}$, a low connected porosity ranging from 0.54 to $0.71 \%$, and a permeability that lies between $1.9 \times 10^{-20}$ and $6.3 \times 10^{-20} \mathrm{~m}^{2}$. These relatively low porosity and permeability are comparable with values commonly observed in granitic rocks [22] and emphasize that granite is not favorable for fluid flow. The matrix density (Figure 10(a)), the connected porosity (Figure 10(b)), and the permeability (Figure $10(\mathrm{c})$ ) increase progressively with the chemical alteration index (AI) and hence with the degree of greisenization. Greisen is characterized by a matrix density ranging from 2.87 to $2.93 \mathrm{~g} . \mathrm{cm}^{-3}$, a connected porosity ranging from 5.86 to $8.97 \%$, and a permeability of $1.24 \times$ $10^{-17} \mathrm{~m}^{2}$. These results show that the mineralogical changes induced by greisen alteration have significant effects on the rock's petrophysical properties and especially on permeability, which increases by three orders of magnitude. This suggests that greisenization probably exerts a strong control on fluid flow, as also do the fracturing and deformation processes $[50,72]$. 


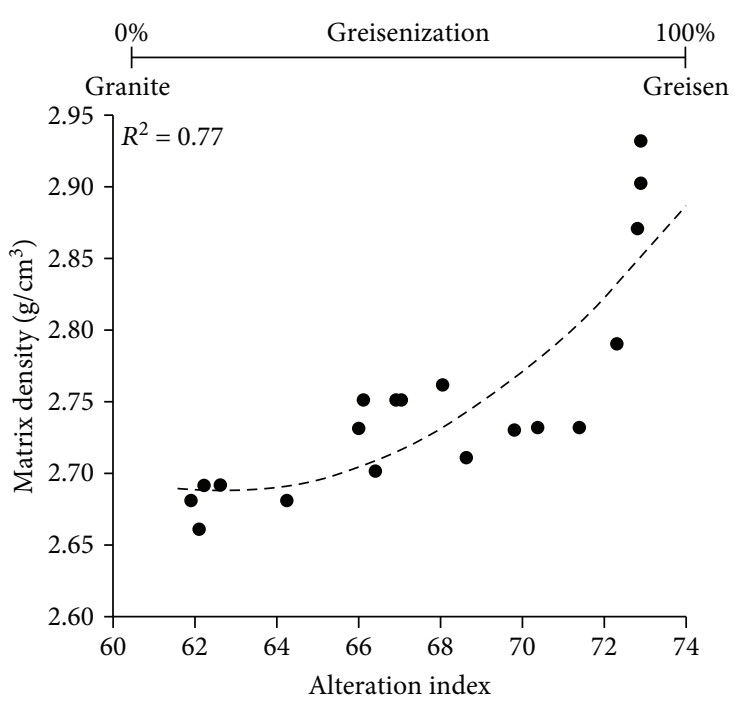

(a)

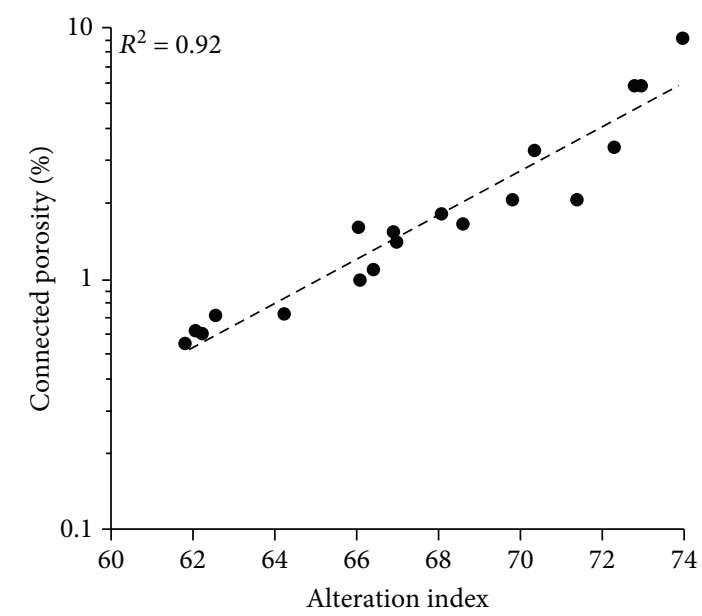

(b)

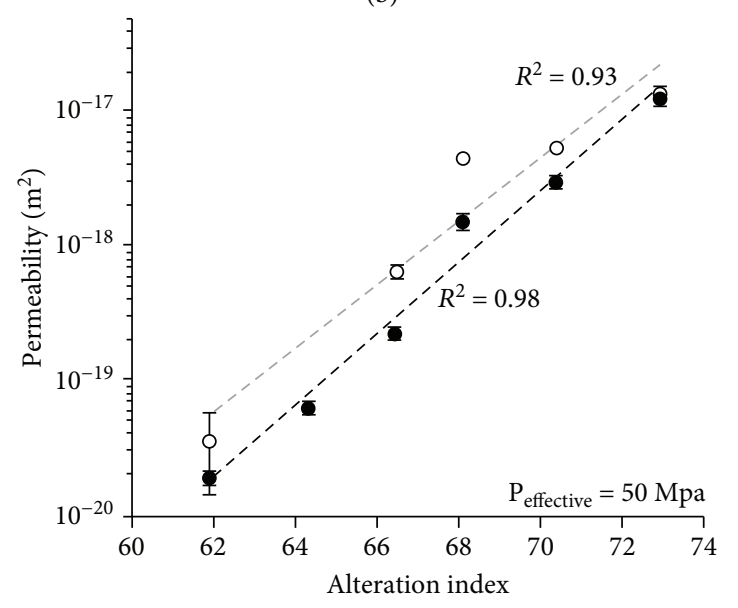

$25^{\circ} \mathrm{C}-100 \mathrm{Mpa}$

- $400^{\circ} \mathrm{C}-100 \mathrm{Mpa}$

(c)

FIGURE 10: Evolution of (a) matrix density, (b) connected porosity, and (c) permeability as a function of the chemical alteration index (AI). The AI increases upon greisen alteration (see the top horizontal qualitative axis and Section 4.3 for explanation).
6.2. Porosity-Density Relationship and Dynamic Permeability. The rock's petrophysical properties appear to be strongly affected by the advance of greisen alteration. Here, we discuss the relationships between the replacement reactions and changes in the rock's petrophysical properties. In Figure 11(a), the evolution of porosity is positively correlated with rock matrix density, which depends directly on the density of minerals constituting the rocks. Accordingly, the metasomatic replacement of less dense minerals (albite $2.61-2.63 \mathrm{~g} . \mathrm{cm}^{-3}$ and $\mathrm{K}$-feldspars $2.54-2.57 \mathrm{~g} . \mathrm{cm}^{-3}$ ) by a large amount of denser muscovite $\left(2.77-2.88 \mathrm{~g} . \mathrm{cm}^{-3}\right)$ is certainly responsible for the overall increase in rock matrix density observed during the greisenization. Consequently, the correlation observed between the porosity and the matrix density emphasizes that the increase in porosity during greisenization was probably caused by replacement reactions related to the greisen alteration described in Section 4. Furthermore, the range of porosity increase $(\sim 8.43 \%)$ indicated by our measurements matches the theoretical porosity estimated from (i) the molar volume decrease $(9.7 \%)$ induced by replacement reactions related to greisenization and (ii) the best isocon (12.4\%) deduced from changes in the whole-rock composition. We conclude that the mineralogical transformations induced by greisen alteration can be an efficient process for generating porosity and hence potential pathways for fluid flow. Finally, the high matrix density values observed in the most altered and porous greisen are certainly due to the presence of dense metal-bearing minerals such as sulfides (pyrite $5.01 \mathrm{~g} . \mathrm{cm}^{-3}$, chalcopyrite $4.2 \mathrm{~g} . \mathrm{cm}^{-3}$ ) and cassiterite $\left(6.9 \mathrm{~g} . \mathrm{cm}^{-3}\right)$ and suggest that greisen was a potential pathway and trap for mineralized fluids.

The development of a porous texture and porosity during greisen alteration seems to be directly related to the replacement reactions involved during greisenization. To highlight the effect of this porosity generation on permeability, we have plotted the evolution of permeability as a function of rock porosity in Figure 11(b). We see that permeability is strongly related to porosity, following an empirical power-law relationship between permeability $(k)$ and porosity $(\varphi)$ :

$$
k=k_{0} \cdot\left(\frac{\varphi}{\varphi_{0}}\right)^{n}
$$

where $\left(k_{0}\right)$ and $\left(\varphi_{0}\right)$ are, respectively, the initial permeability and porosity of the unaltered granite and $(n)$ a coefficient depending on pore geometry and the material's grain size. In this study, permeability and porosity values fit the power law for $n$ ranging from 3 to 4 . This cubic dependence relationship has been used and adopted in several studies to define permeability evolution in natural systems [72-75].

This strong interdependence between greisen porosity and permeability emphasizes that the porosity generated by the replacement reactions is responsible for the strong increase in permeability observed during greisenization. Accordingly, greisenization is probably an example of the "reaction-enhanced permeability" process described by Putnis [26] and also seen elsewhere [27]. Greisen alteration is evidently able to generate permeable pathways that could 


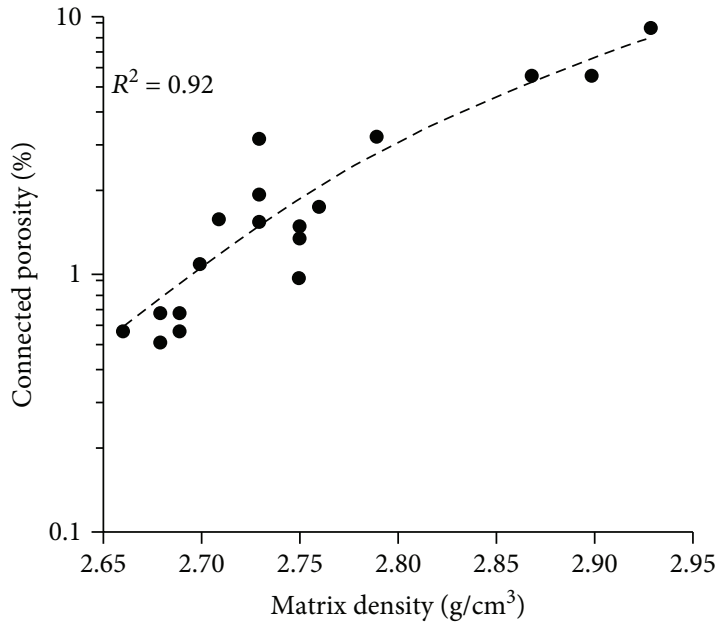

(a)

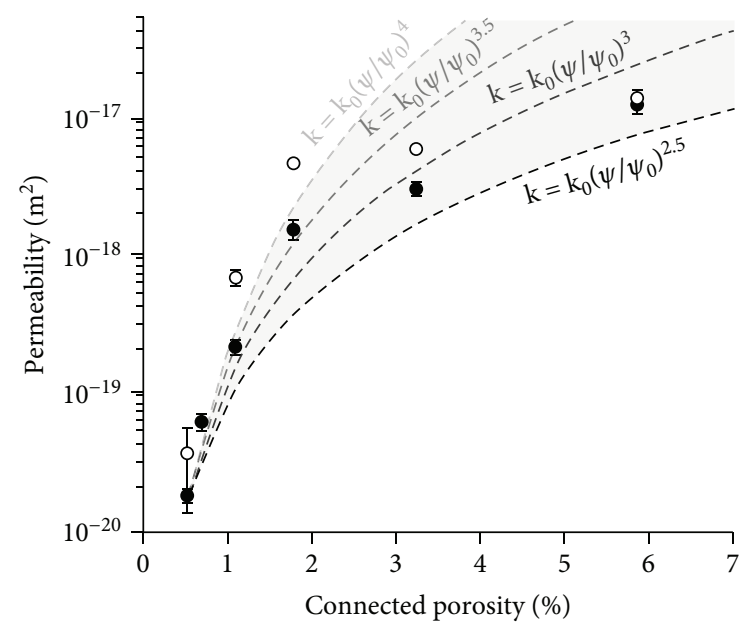

(b)

Figure 11: (a) Relationship between matrix density and connected porosity deduced from measurements performed on the Panasqueira granite-greisen samples. (b) Relationship between connected porosity and permeability deduced from granite greisen samples in which porosity and permeability were measured. Black and white dots correspond, respectively, to permeability values obtained at $25^{\circ} \mathrm{C}$ and $400^{\circ} \mathrm{C}$. The dashed line corresponds to modeled evolutions of permeability as a function of rock porosity using power law equations (see text for explanations).

enhance fluid flow and promote further alteration. This positive feedback between alteration and permeability may constitute a potential explanation for the development of massive greisens found in numerous $\mathrm{Sn}-\mathrm{W}$ deposits.

\section{Permeability Change during Greisenization: Implications for Fluid Flow}

7.1. Massive Greisen: A Potential Pathway for Mineralized Fluids? The transient porosity-permeability developed during greisenization can affect large-scale mass transport and propagation of the alteration in a granite massif. To discuss the implications of the permeability change during greisenization, permeability values were plotted on the vertical profile of the SCB2 drill hole (Figure 12(a)). Additionally, the whole-rock composition in $\mathrm{Sn}, \mathrm{W}$, and $\mathrm{Cu}$ was added to this profile to establish a potential link between the rock permeability and metal content. As expected, the permeability increases up to the granite's roof and is highest along the granite-schist contact, where granite was totally converted to greisen. In contrast, the low permeability and the low reactivity of the metasedimentary host rock $\left(1.52 \times 10^{-21} \mathrm{~m}^{2}\right)$ suggest that fluid flow was probably controlled by the permeable greisen that forms the apical portion of the granite intrusion. Moreover, the impermeable nature of the overlying metasedimentary host rocks could promote the greisenization of the granite by inhibiting the expulsion of fluid from the granite's roof. The correlation between permeability and concentration of $\mathrm{Sn}, \mathrm{W}$, and $\mathrm{Cu}$ provides evidence that fluids related to the $\mathrm{Sn}-\mathrm{W}$ and sulfide stages in the mineralized Panasqueira vein system have flowed through greisen. The occurrences of euhedral quartz (Figure 5(e)), metal-bearing minerals such as cassiterite (Figure 12(b)), and sulfides (chalcopyrite, sphalerite, and pyrite) (Figures $12(\mathrm{c})$ and $12(\mathrm{~d})$ ) that partially fill the neoformed porosity corroborate this interpretation. In addition, the presence of sulfides in the cleavage planes of muscovite (Figure 12(e)) shows that the formation of large amounts of muscovite during the greisenization provides another type of pathway that connects the intergranular pores and could enhance fluid flow. In light of these observations, greisen appears to be a preferential pathway for mineralized fluids; hence, increased permeability related to greisenization may provide an important mechanism for enhancing fluid flow and forming Sn-W deposits.

7.2. Application to Other Greisen Systems. As shown previously, the evolution of matrix density constitutes a useful monitor for following the progressive mineralogical transformation of the granitic rocks during greisenization (replacement of less dense minerals by denser ones). Owing to the lack of permeability data on greisen systems, and given the relationship between porosity and permeability, we have plotted the evolution of porosity as a function of matrix density to discuss the effect of greisen alteration on metal transport for several greisen systems associated with Sn-W mineralization (Figure 13(a)). The positive correlation between matrix density and porosity described in the Panasqueira greisen system can also be observed in other greisen systems, as shown in Figure 13(a). Additionally, the range of porosity increase usually appears to be similar from one greisen system to another (maximum porosity of about $10 \%$ ). Accordingly, the process of porosity generation induced by the replacement reactions (monitored by the rock's matrix density) is evidently a common process in greisen systems. It follows that the permeability increase triggered by porosity generation may be a crucial mechanism for enhancing fluid flow and thereby metal transport in granitic intrusions related to $\mathrm{Sn}-\mathrm{W}$ deposits. Figure 13(b) indicates that greisen can form low-grade ( 0.1 to $0.4 \mathrm{wt} \%)$ 

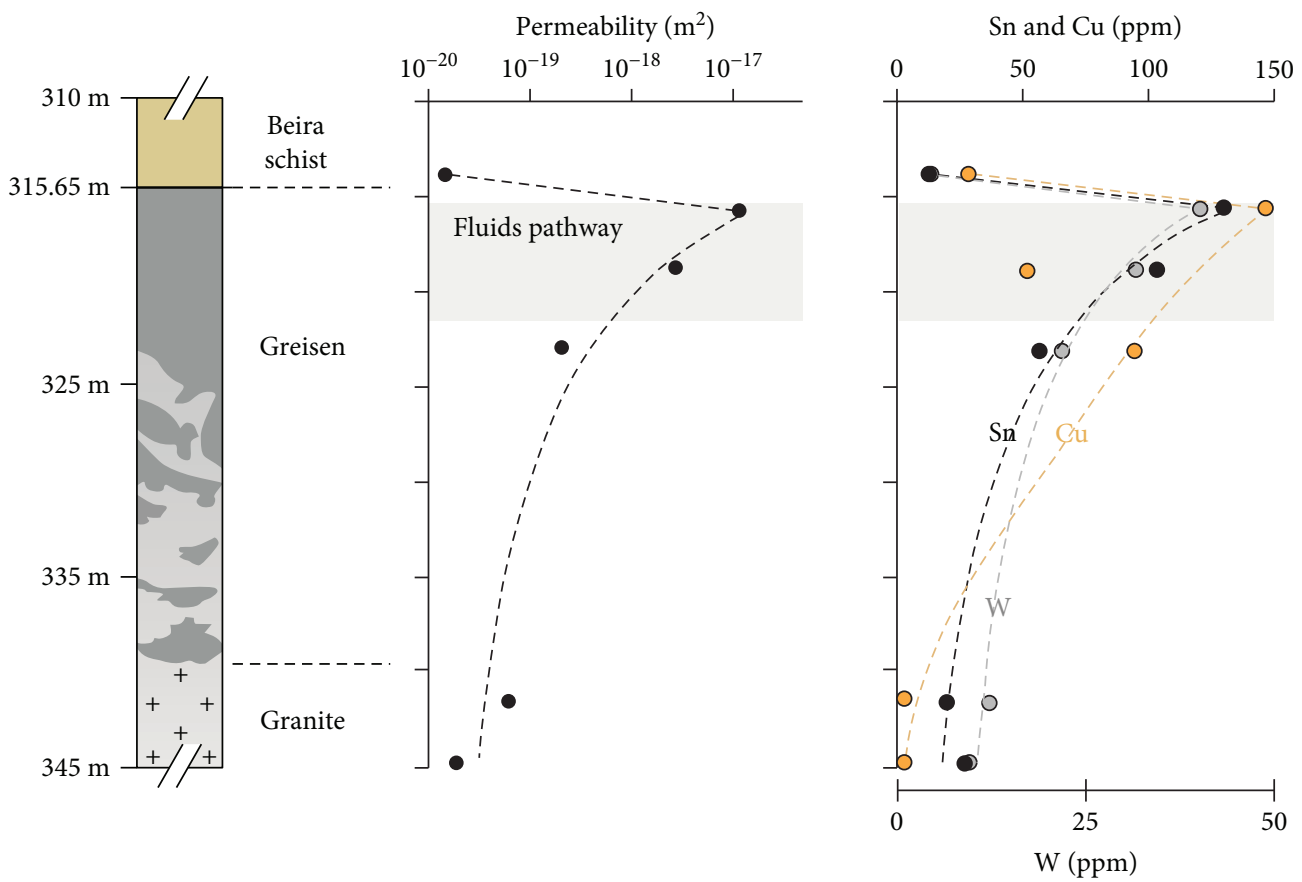

(a)

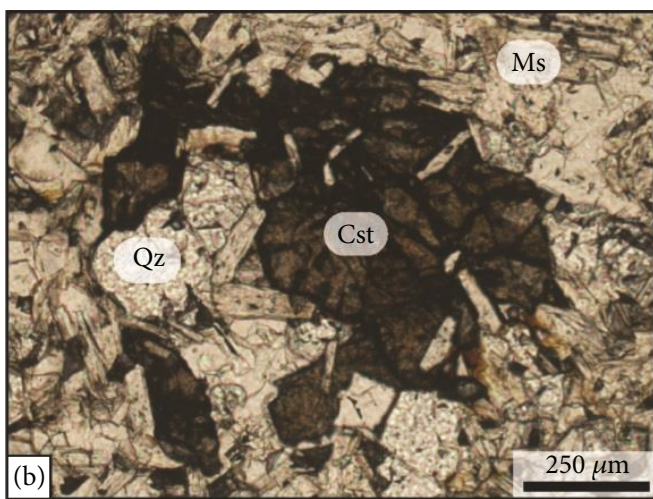

(b)

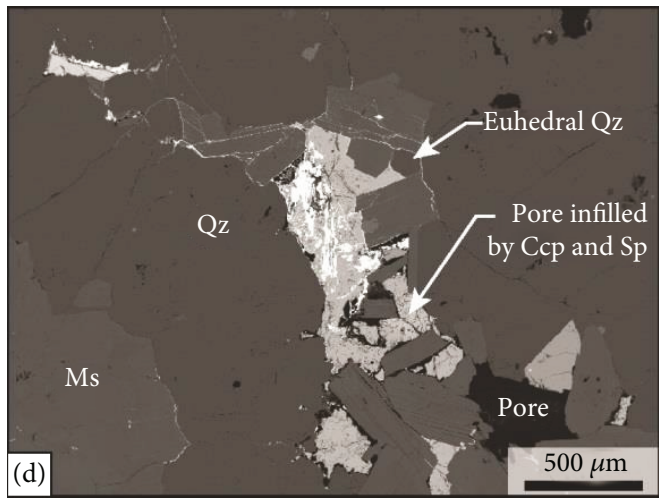

(d)

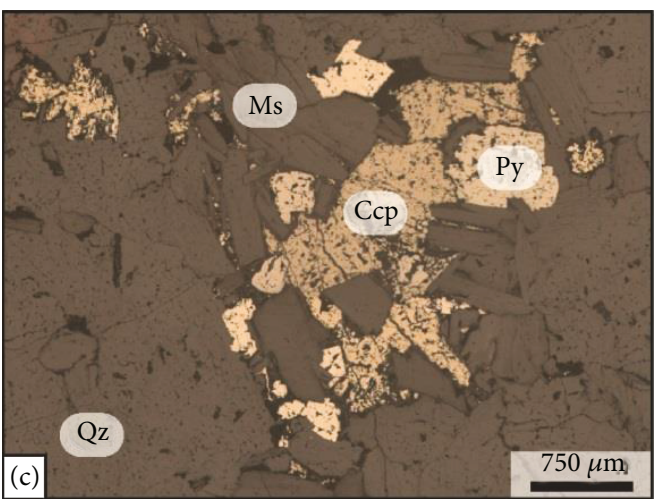

(c)

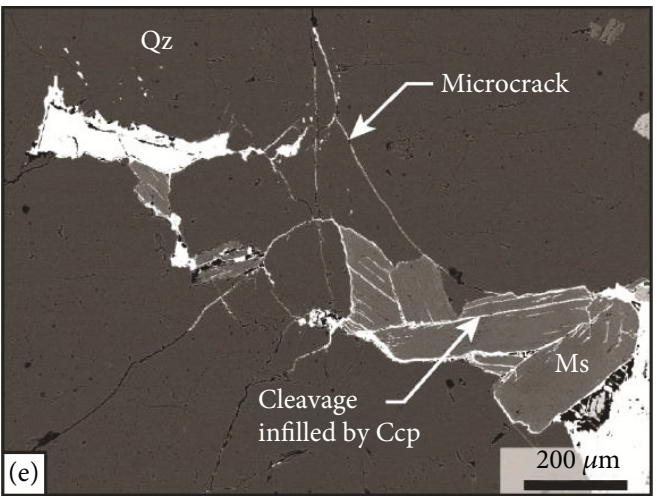

(e)

FIGURE 12: (a) Vertical evolution of the permeability and whole-rock Sn, W, and Cu contents in drill hole SCB2. The spatial correlation between rock permeability and in metal contents suggests that greisen was probably a preferential pathway for fluids related to the main mineralization stages occurring in the Panasqueira vein system. Greisen pores infilled by ore-bearing minerals: (b) cassiterite (transmitted light), (b) chalcopyrite (reflected light), and (d-e) chalcopyrite and sphalerite (SEM-BSE images). Note the presence of sulfides within the cleavage planes of muscovite suggesting that these weakness planes may be potential pathways for fluids. Abbreviations from Whitney and Evans [45]: Ccp: chalcopyrite; Cst: cassiterite; Ms: muscovite; Py: pyrite; Qz: quartz; Sp: sphalerite. 


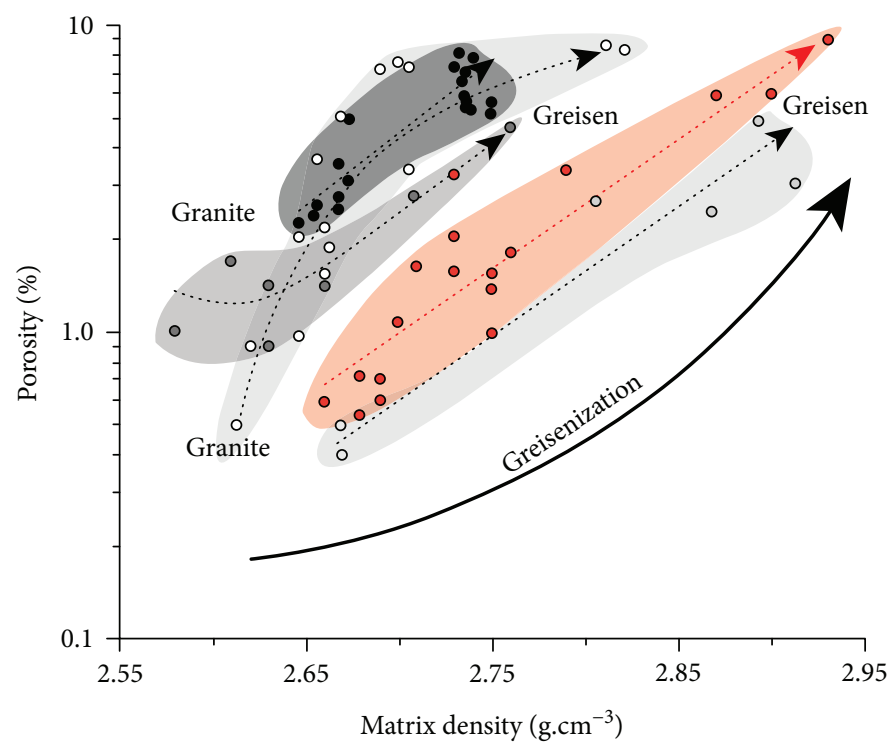

- Panasqueira (Portugal) this study

- Nebelstein (Austria)

Müller-Huber et al., 2017

○ Karlovy Vary massif (Czech Republic)

Blecha et al., 2012
○ Vysoký Kàmen stock (Czech Republic)

Machek et al., 2013

O East Kemptville (Canada) Halter et al., 1996

(a)

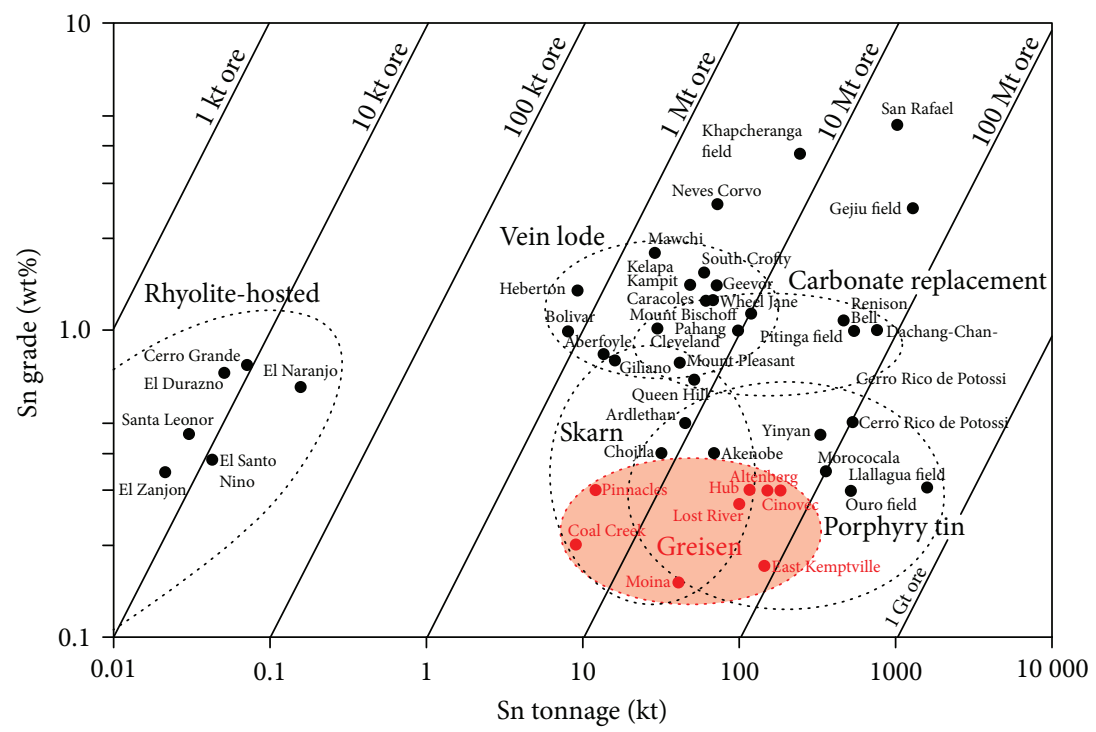

(b)

FIgure 13: (a) Compilation of matrix density and porosity data measured in various granite-greisen systems. This compilation shows that increases in matrix density and porosity are common in greisen systems. It also suggests that feedback between greisen alteration and permeability may be a common process in this type of deposit. (b) Grade versus metal content for several types of large, high-grade, primary tin deposits (modified from [76]). Note that greisen systems can form high-tonnage, low-grade tin deposits.

and high-tonnage (100 to $500 \mathrm{kt}) \mathrm{Sn}$ deposits such as Sn-porphyry and skarn $[21,76]$. This emphasizes that despite the initial low permeability of the parental granite, greisen becomes porous and permeable enough to permit fluid flow and to trap metals. The process of reaction-enhanced permeability related to greisenization may be required to enhance $\mathrm{Sn}-\mathrm{W}$ metal transport and hence to form this type of deposit. Moreover, deposits such as the Panasqueira greisens are frequently associated with a network of mineralized veins or lodes $[1,7,21]$.

\section{Summary and Conclusion}

We have investigated the effects of the mineralogical changes produced by greisenization on rock porosity and permeability by coupling experimental and petrophysical 

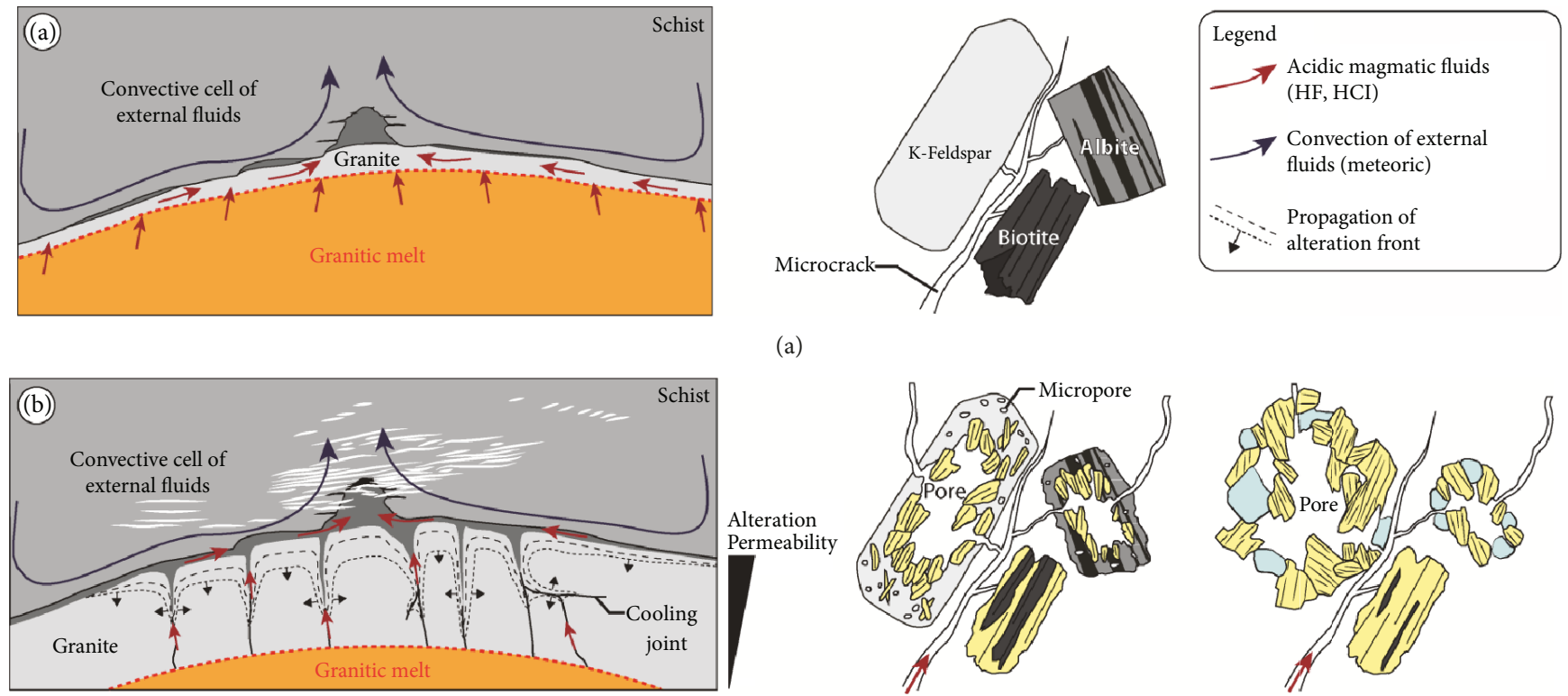

(b)
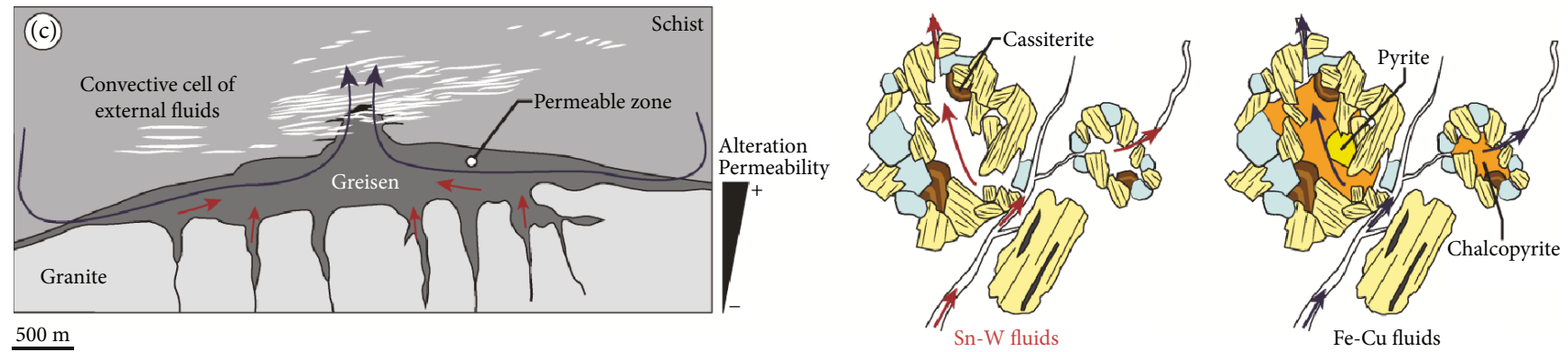

(c)

Figure 14: Conceptual model incorporating the evolution of permeability over time induced by replacement reactions related to greisenization of the Panasqueira granite. (a) Initiation of granite cooling and fluid flow, which trigger the greisenization of the granite along the granite-schist contact (permeable interface). (b) Alteration of the granite leading to the progressive replacement of feldspars and biotite by muscovite. This mineralogical transformation is accompanied by the generation of porosity resulting from the decrease in molar volume associated with the replacement reactions. A positive feedback between greisen alteration and permeability is assumed here to explain the propagation of the greisenization front and the development of massive greisen. (c) The porosity generated by the greisen alteration enhances permeability and creates a potential permeable zone that can enhance fluid flow and metal transport. The presence of metal bearing-minerals (cassiterite and sulfides) in the newly formed greisen's porosity seems to confirm the role of massive greisen as a drain for mineralizing fluids and to explain the formation of this type of deposit.

approaches. To summarize our results, we propose a conceptual model of greisenization and fluid flow, in which the evolution of permeability is considered (Figure 14). In this model, we assume that greisenization takes place during the magmatic-hydrothermal transition and just after the early alkali metasomatism of feldspars (K-metasomatism and albitization). This early metasomatic alteration, which results likely from interaction with orthomagmatic fluids, is responsible for the conversion of the original magmatic feldspar phases into the now observed orthoclase (Or100) and albite (Ab100). At the initiation of this model (Figure 14(a)), the granite-schist interface was probably a permeable one, in which fluids preferentially flowed and initiate the greisenization of the granite's roof. This is consistent with the vertical zoning of the greisen alteration observed at Panasqueira and in several other greisen systems associated with Sn-W deposits. This alteration triggers the replacement feldspars and biotite that starts along grain boundaries, along the cleavage planes of feldspars and from micropores developed in albite by CDP reactions during the early albitization stage. The decrease in molar volume caused by these replacement reactions produces higher-density phases (muscovite) and progressively generates porosity, which increases significantly the permeability of greisen. A positive feedback between greisenization and permeability is proposed, to explain the propagation of the alteration front toward the deeper portion of the granite intrusion and the formation of the massive greisen commonly observed in Sn-W deposits (Figure 14(b)). As a consequence, this enhancement of permeability would promote fluid flow and metal transport through the massive greisen leading to the deposition of metal-bearing minerals (cassiterite and sulfides) in the newly formed greisen porosity. This may be a process of greater importance than 
previously assumed in the formation of large greisen deposits (Figure 14(c)). Furthermore, the permeable greisen could also constitute a significant drain into which fluids released by the underlying granite and the surrounding convecting fluids could be focused and directed towards structural traps to form vein deposits.

Finally, this study emphasizes that mineralizing fluids are able to generate their own pathways in an initially impermeable granite by means of the replacement reactions related to greisenization. This reaction-enhanced permeability process is rarely discussed in hydrothermal systems associated with ore deposits. Here, we demonstrate in the case of greisenization that replacement reactions involved in numerous hydrothermal alterations can provide an efficient process for creating the high-permeability pathways required for vigorous fluid flow and for the self-propagating of pervasive alterations. All these experimentally deduced fluid flow processes should be tested by numerical models of hydrothermal processes surrounding cooling granite intrusions, including dynamic permeability during greisenization. Such a numerical approach would provide quantitative information about the effects of permeability change on the fluid flow pattern and thus on metal transport and deposition in $\mathrm{Sn}-\mathrm{W}$ deposits.

\section{Data Availability}

The porosity, density, and permeability data used to support the findings of this study are included within the article (Table 2). The EPMA analyses of feldspars used to support the findings are included within the supplementary information (ESM 3). The XRD data used to support this study are included in the supplementary information files (ESM 5). The whole-rock composition data used to support our findings are included in the supplementary information files (ESM 8). The data on the evolution of permeability over time used to support this study are included within the article (Figure 8 Section 5.1).

\section{Disclosure}

Part of this work was presented in poster form and extending abstract to the Society for Geology Applied to Mineral Deposits of 2017.

\section{Conflicts of Interest}

The authors declare that there are no conflicts of interest for publication of this article.

\section{Acknowledgments}

We are most grateful to Beralt Tin \& Wolfram S.A. for permitting access to the Panasqueira underground mine and for permitting the collection of samples from the SCB2 drill-cores, which were indispensable for this study. We would also like to thank Hubert Haas (BRGM labs) for his help with the porosity and density measurements. We are grateful to Dr. Daniel Kontak (Laurentian University) for his constructive and relevant remarks, which have greatly improved this manuscript. We thank J. Guy-Bray for his English corrections and revisions. This research formed part of the ERAMIN project "New Ores" (ANR-14-EMIN-0001) and was financially supported by the French Geological Survey (Bureau de Recherches Géologiques et Minières) and Region Centre-Labex Voltaire (ANR-10-LABX-100-01).

\section{Supplementary Materials}

A supplementary materials file is attached to this article comprising the following. ESM 1: schematic representation of the Paterson apparatus and the pore-fluid pressure system used for the permeability measurements. This figure also displays an example of a permeability measurement performed on the unaltered granite sample (E2). From the monitored volume of fluid injected into the sample over the experimental period, the flow rate through the sample core was calculated from a linear regression $(Q=d V / d t)$. From this flow rate and the pressure difference, the permeability was calculated. ESM 2: photomicrographs of K-feldspars and albite from the two-mica Panasqueira granite and greisenized granite. (a to c) Photomicrograph of matrix K-feldspars exhibiting replacement textures related to the early alkali metasomatism (a and $\mathrm{c}$ photomicrograph in transmitted light, $\mathrm{b}$ and $\mathrm{d}$ cathodoluminescence images). (e) Photomicrograph of K-feldspars exhibiting perthitic texture (transmitted polarized light). (f) Photomicrograph of albite in granite matrix (polarized transmitted light). ( $g$ and $h$ ) Relics of albite partially replaced by muscovite (polarized transmitted light). ESM 3: tables of EPMA analyses of alkali feldspars and plagioclase from the least altered two-mica Panasqueira granite. ESM 4: more SEM-BSE images showing the microtextural characteristics of greisenized Panasqueira granite and greisen. (a) Section of K-feldspars partially altered into muscovite during greisenization. Note the presence of micropores and microcracks completely filled by sulfide minerals (pyrite and chalcopyrite) during the late sulfide stage. (b) Section of greisenized granite exhibiting microporous texture. (c) Section of quartz-muscovite greisen with large pores, cracks, and microcracks. (d and e) Enlarged view of greisen pores, in which apatite, cassiterite, and euhedral quartz have crystallized. (f) Greisen pores completely filled by sphalerite and chalcopyrite. ESM 5: X-ray diffractogram (XRD) obtained from a powder sample of less altered Panasqueira granite. This diffractogram was used to determine the volumetric abundances of the primary magmatic minerals constituting the granite. Estimation of mineral abundances was performed using the Rietveld method. ESM 6 More SEM-BSE images showing the alteration products and textures produces during the greisenization experiment. These photomicrographs supplement observations made in Section 5.2. ESM 7: SEM-BSE images and geochemical mapping of $\mathrm{K}$ showing the pathways along which fluids preferentially flowed and altered albite to muscovite during the greisenization experiment. This figure provides supporting information for the discussion of results obtained during the greisenization experiments (Section 5.2). ESM 8: tables of major ( $w t \%$ ) and trace (ppm) elemental compositions for granite, 
greisenized granite, and greisen used to construct the isocon diagram (Section 4.3) and to establish the chemical alteration index (AI) for samples, in which petrophysical properties were determined. (Supplementary Materials)

\section{References}

[1] P. Černý, P. L. Blevin, M. Cuney, and D. London, "Granite-related ore deposits," in Economic Geology - One Hundredth Anniversary, J. W. Hedenquist, J. F. H. Thompson, R. J. Goldfarb, and J. R. Richards, Eds., pp. 337-370, Society of Economic Geologists, 2005.

[2] F. Pirajno, "Greisen systems," in Hydrothermal Mineral Deposits, pp. 280-324, Springer, Berlin, Heidelberg, 1992.

[3] P. J. Pollard, R. G. Taylor, and C. Cuff, "Genetic modelling of greisen-style tin systems," in Geology of Tin Deposits in Asia and the Pacific, C. S. Hutchison, Ed., pp. 59-72, Springer, Berlin, Heidelberg, 1988.

[4] M. Stemprok, "Greisenization," in Geol Rundsch, vol. 76, p. 169, Springer, 1987.

[5] A. C. Bishop, "Greisen," in Petrology. Encyclopedia of Earth Science, Springer, Boston, MA, 1989.

[6] G. N. Shcherba, "Greisens," International Geology Review, vol. 12, no. 2, pp. 114-150, 2009.

[7] R. G. Taylor and P. J. Pollard, "Pervasive hydrothermal alteration in tin-bearing granite and implications for the evolution of ore-bearing magmatic fluids," Granite related Mineral Deposits, Recent Advances in Geology, vol. 39, pp. 86-95, 1988.

[8] G. P. Zaraisky and F. M. Stoyanovskaya, "Experimental modeling of gain and loss of rare metals (W, Mo, Sn) during greisenization and alkalic metasomatism of leucocratic granite," Experiment in Geosciences, vol. 4, pp. 19-21, 1995.

[9] J. Dostal, D. J. Kontak, and S. M. Karl, "The Early Jurassic Bokan Mountain peralkaline granitic complex (southeastern Alaska): geochemistry, petrogenesis and rare-metal mineralization," Lithos, vol. 202-203, pp. 395-412, 2014.

[10] J. Dostal, D. J. Kontak, O. Gerel, J. Gregory Shellnutt, and M. Fayek, "Cretaceous ongonites (topaz-bearing albite-rich microleucogranites) from Ongon Khairkhan, Central Mongolia: products of extreme magmatic fractionation and pervasive metasomatic fluid: rock interaction," Lithos, vol. 236-237, pp. 173-189, 2015.

[11] D. J. Kontak and A. H. Clark, "Genesis of the Giant, bonanza San Rafael lode tin deposit, Peru: origin and significance of pervasive alteration," Economic Geology, vol. 97, no. 8, pp. 1741-1777, 2002.

[12] O. Plümper and A. Putnis, “The complex hydrothermal history of granitic rocks: multiple feldspar replacement reactions under subsolidus conditions," Journal of Petrology, vol. 50, no. 5, pp. 967-987, 2009.

[13] L. Jonas, T. John, H. E. King, T. Geisler, and A. Putnis, “The role of grain boundaries and transient porosity in rocks as fluid pathways for reaction front propagation," Earth and Planetary Science Letters, vol. 386, pp. 64-74, 2014.

[14] A. Putnis, "Transient porosity resulting from fluid-mineral interaction and its consequences," Reviews in Mineralogy and Geochemistry, vol. 80, no. 1, pp. 1-23, 2015.

[15] A. Hall, "Greisenisation in the granite of Cligga Head Cornwall," Proceedings of the Geologists' Association, vol. 82, no. 2, pp. 209-IN1, 1971.
[16] W. E. Halter, A. E. Williams-Jones, and D. J. Kontak, “The role of greisenization in cassiterite precipitation at the East Kemptville tin deposit, Nova Scotia," Economic Geology, vol. 91, no. 2, pp. 368-385, 1996.

[17] W. E. Halter, A. E. Williams-Jones, and D. J. Kontak, "Origin and evolution of the greisenizing fluid at the East Kemptville tin deposit, Nova Scotia, Canada," Economic Geology, vol. 93, no. 7, pp. 1026-1051, 1998.

[18] W. C. Kelly and R. O. Rye, "Geologic, fluid inclusion, and stable isotope studies of the tin-tungsten deposits of Panasqueira, Portugal," Economic Geology, vol. 74, no. 8, pp. 1721-1822, 1979.

[19] M. Stemprok, E. Pivec, and A. Langrova, “The petrogenesis of a wolframite-bearing greisen in the Vykmanov granite stock, Western Krušné hory pluton (Czech Republic)," Bulletin of Geosciences, vol. 80, no. 3, pp. 163-184, 2005.

[20] D. Thadeu, "Geologia do couto mineiro da Panasqueira," Comunic Serv Geol Port, vol. 32, pp. 5-64, 1951.

[21] R. G. Taylor, "Geology of tin deposits," in Developments in Economic Geology, vol. 11, p. 543, Elsevier, 1979.

[22] S. E. Ingebritsen and M. S. Appold, "The physical hydrogeology of ore deposits," Economic Geology, vol. 107, no. 4, pp. 559-584, 2012.

[23] S. E. Ingebritsen and T. Gleeson, "Crustal permeability: introduction to the special issue," Geofluids, vol. 15, no. 1-2, 10 pages, 2015.

[24] M. A. Booden, J. L. Mauk, and M. P. Simpson, "Quantifying metasomatism in epithermal $\mathrm{Au}-\mathrm{Ag}$ deposits: a case study from the Waitekauri area, New Zealand," Economic Geology, vol. 106, no. 6, pp. 999-1030, 2011.

[25] K. Pollok, C. V. Putnis, and A. Putnis, "Mineral replacement reactions in solid solution-aqueous solution systems: volume changes, reactions paths and end-points using the example of model salt systems," American Journal of Science, vol. 311, no. 3, pp. 211-236, 2011.

[26] A. Putnis, "Mineral replacement reactions: from macroscopic observations to microscopic mechanisms," Mineralogical Magazine, vol. 66, no. 5, pp. 689-708, 2002.

[27] A. Putnis and H. Austrheim, "Fluid-induced processes: metasomatism and metamorphism," Geofluids, vol. 10, p. 269, 2010.

[28] A. Putnis and T. John, "Replacement processes in the earth's crust," Elements, vol. 6, no. 3, pp. 159-164, 2010.

[29] K. Iyer, B. Jamtveit, J. Mathiesen, A. Malthesorenssen, and J. Feder, "Reaction-assisted hierarchical fracturing during serpentinization," Earth and Planetary Science Letters, vol. 267, no. 3-4, pp. 503-516, 2008.

[30] B. Jamtveit, H. Austrheim, and A. Malthe-Sorenssen, "Accelerated hydration of the Earth's deep crust induced by stress perturbations," Nature, vol. 408, no. 6808, pp. 75-78, 2000.

[31] B. Jamtveit, A. Malthesorenssen, and O. Kostenko, "Reaction enhanced permeability during retrogressive metamorphism," Earth and Planetary Science Letters, vol. 267, no. 3-4, pp. 620-627, 2008.

[32] D. J. Kontak and K. Kyser, "A fluid inclusion and isotopic study of an intrusion-related gold deposit (IRGD) setting in the 380 Ma South Mountain Batholith, Nova Scotia, Canada: evidence for multiple fluid reservoirs," Mineralium Deposita, vol. 46, no. 4, pp. 337-363, 2011.

[33] M. Štemprok, D. Dolejš, and F. V. Holub, "Late Variscan calc-alkaline lamprophyres in the Krupka ore district, Eastern 
Krušné hory/Erzgebirge: their relationship to Sn-W mineralization," Journal of Geosciences, vol. 59, no. 1, pp. 41-68, 2014.

[34] M. Julivert, J. M. Fontboté, A. Ribeiro, and L. Conde, Mapa Tectonico de la Peninsula Iberica y Baleares E. 1:1.000, Inst. Geol. Min, España, Madrid, 1972.

[35] G. Launay, S. Sizaret, L. Guillou-Frottier, E. Gloaguen, and F. Pinto, "Deciphering fluid flow at the magmatichydrothermal transition: a case study from the world-class Panasqueira W-Sn-(Cu) ore deposit (Portugal)," Earth and Planetary Science Letters, vol. 499, pp. 1-12, 2018.

[36] A. N. Castro, L. G. Corretgé, J. E. De la Rosa et al., "Palaeozoic magmatism," in The Geology of Spain, pp. 117-153, Geological Society, London, 2002.

[37] G. Dias, J. Leterrier, A. Mendes, P. P. Simões, and J. M. Bertrand, "U-Pb zircon and monazite geochronology of post-collisional Hercynian granitoids from the Central Iberian Zone (Northern Portugal)," Lithos, vol. 45, no. 1-4, pp. 349-369, 1998.

[38] M. F. Pereira, A. Castro, and C. Fernandez, "The inception of a Paleotethyan magmatic arc in Iberia," Geoscience Frontiers, vol. 6, no. 2, pp. 297-306, 2015.

[39] R. W. Bussink, "Geochemistry of the Panasqueira tungsten-tin deposit, Portugal," Geologica Ultraiectina, vol. 33, pp. 1-170, 1984.

[40] A. H. Clark, "Preliminary study of the temperatures and confining pressures of granite emplacement and mineralization, Panasqueira, Portugal," Institute Mining Metallurgy Transactions, vol. 73, pp. 813-824, 1964.

[41] R. P. B. Hebblethwaite and A. M. Antao, A Report on the Study of Dilation Patterns within the Panasqueira Ore Body: Barroca Grande, Beralt Tin Wolfram, Portugal, 1982.

[42] D. A. Polya, K. A. Foxford, F. Stuart, A. Boyce, and A. E. Fallick, "Evolution and paragenetic context of low $\delta \mathrm{D}$ hydrothermal fluids from the Panasqueira W-Sn deposit, Portugal: new evidence from microthermometric, stable isotope, noble gas and halogen analyses of primary fluid inclusions," Geochimica et Cosmochimica Acta, vol. 64, no. 19, pp. 3357-3371, 2000.

[43] V. Lueders, "Contribution of infrared microscopy to fluid inclusion studies in some opaque minerals (Wolframite, Stibnite, Bournonite) : metallogenic implications," Economic Geology, vol. 91, no. 8, pp. 1462-1468, 1996.

[44] F. Noronha, A. Doria, J. Dubessy, and B. Charoy, "Characterization and timing of the different types of fluids present in the barren and ore-veins of the W-Sn deposit of Panasqueira, Central Portugal,” Mineralium Deposita, vol. 27, no. 1, 1992.

[45] D. L. Whitney and B. W. Evans, "Abbreviations for names of rock-forming minerals," American Mineralogist, vol. 95, no. 1, pp. 185-187, 2009.

[46] J. W. Johnson, E. H. Oelkers, and H. C. Helgeson, "SUPCRT92: A software package for calculating the standard molal thermodynamic properties of minerals, gases, aqueous species, and reactions from 1 to 5000 bar and 0 to $1000^{\circ} \mathrm{C}$," Computers \& Geosciences, vol. 18, no. 7, pp. 899-947, 1992.

[47] K. Zimmer, Y. Zhang, P. Lu et al., "SUPCRTBL: a revised and extended thermodynamic dataset and software package of SUPCRT92," Computers \& Geosciences, vol. 90, pp. 97-111, 2016.

[48] G. Coelho, Y. Branquet, S. Sizaret, L. Arbaret, R. Champallier, and O. Rozenbaum, "Permeability of sheeted dykes beneath oceanic ridges: strain experiments coupled with $3 \mathrm{D}$ numerical modeling of the Troodos Ophiolite, Cyprus," Tectonophysics, vol. 644-645, pp. 138-150, 2015.

[49] E. Tenthorey and S. F. Cox, "Reaction-enhanced permeability during serpentinite dehydration," Geology, vol. 31, no. 10, p. 921, 2003.

[50] E. Tenthorey and J. Fitzgerald, "Feedbacks between deformation, hydrothermal reaction and permeability evolution in the crust: experimental insights," Earth and Planetary Science Letters, vol. 247, no. 1-2, pp. 117-129, 2006.

[51] M. S. Paterson and D. L. Olgaard, "Rock deformation tests to large shear strains in torsion," Journal of Structural Geology, vol. 22, no. 9, pp. 1341-1358, 2000.

[52] A. A. Finch and F. D. L. Walker, "Cathodoluminescence and microporosity in alkali feldspars from the Blå Måne Sø perthosite, South Greenland," Mineralogical Magazine, vol. 55, no. 381, pp. 583-589, 1991.

[53] M. R. Lee, I. Parsons, P. R. Edwards, and R. W. Martin, "Identification of cathodoluminescence activators in zoned alkali feldspars by hyperspectral imaging and electron-probe microanalysis," American Mineralogist, vol. 92, no. 2-3, pp. 243-253, 2007.

[54] A. N. Mariano, Simposio Internacional de Carbonatitos, Pocos de Caldas, 1976.

[55] J. V. Smith and R. C. Stenstrom, Journal of Geology, vol. 73, no. 4, pp. 627-635, 1965.

[56] F. Pirajno, Hydrothermal Processes and Mineral Systems, Springer, Dordrecht, 2009.

[57] D. J. Kontak, "The East Kemptville muscovite-topaz leucogranite. I. Geological setting and whole rock geochemistry," The Canadian Mineralogist, vol. 28, pp. 787-825, 1990.

[58] D. J. Kontak, "Nature and origin of an LCT-suite pegmatite with late-stage sodium enrichment, Brazil Lake, Yarmouth County, Nova Scotia. I. Geological setting and petrology," Canadian Mineralogist, vol. 44, no. 3, pp. 563-598, 2006.

[59] K. Pandur, K. M. Ansdell, D. J. Kontak, K. M. Halpin, and S. Creighton, "Petrographic and mineral chemical characteristics of the Hoidas Lake deposit, northern Saskatchewan, Canada: constraints on the origin of a distal magmatichydrothermal REE system," Economic Geology, vol. 111, no. 3, pp. 667-694, 2016.

[60] A. K. Engvik, P. M. Ihlen, and H. Austrheim, "Characterisation of Na-metasomatism in the Sveconorwegian Bamble sector of South Norway," Geoscience Frontiers, vol. 5, no. 5, pp. 659672, 2014.

[61] M. E. P. Gomes and A. M. R. Neiva, "Chemical zoning of muscovite from the Ervedosa granite, northern Portugal," Mineralogical Magazine, vol. 64, no. 2, pp. 347-358, 2000.

[62] J. A. Grant, "The isocon diagram; a simple solution to Gresens' equation for metasomatic alteration," Economic Geology, vol. 81, no. 8, pp. 1976-1982, 1986.

[63] J. A. Grant, "Isocon analysis: a brief review of the method and applications," Physics and Chemistry of the Earth, vol. 30, no. 17-18, pp. 997-1004, 2005.

[64] K. Mayer, B. Scheu, C. Montanaro et al., "Hydrothermal alteration of surficial rocks at Solfatara (Campi Flegrei): petrophysical properties and implications for phreatic eruption processes," Journal of Volcanology and Geothermal Research, vol. 320, pp. 128-143, 2016.

[65] H. W. Nesbitt and G. M. Young, "Early Proterozoic climates and plate motions inferred from major element chemistry of lutites," Nature, vol. 299, no. 5885, pp. 715-717, 1982. 
[66] A. Pola, G. Crosta, N. Fusi, V. Barberini, and G. Norini, "Influence of alteration on physical properties of volcanic rocks," Tectonophysics, vol. 566-567, pp. 67-86, 2012.

[67] D. A. Polya, "Chemistry of the main-stage ore-forming fluids of the Panasqueira W-Cu(Ag)-Sn deposit, Portugal; implications for models of ore genesis," Economic Geology, vol. 84, no. 5, pp. 1134-1152, 1989.

[68] D. E. Moore, C. A. Morrow, and J. D. Byerlee, "Chemical reactions accompanying fluid flow through granite held in a temperature gradient," Geochimica et Cosmochimica Acta, vol. 47, no. 3, pp. 445-453, 1983.

[69] A. P. S. Selvadurai, M. J. Boulon, and T. S. Nguyen, "The permeability of an intact granite," Pure and Applied Geophysics, vol. 162, no. 2, pp. 373-407, 2005.

[70] C. A. Morrow, D. E. Moore, and D. A. Lockner, "Permeability reduction in granite under hydrothermal conditions," Journal of Geophysical Research, vol. 106, no. B12, pp. 30551-30560, 2001.

[71] R. B. Schmidt, K. Bucher, and I. Stober, "Experiments on granite alteration under geothermal reservoir conditions and the initiation of fracture evolution," European Journal of Mineralogy, vol. 30, no. 5, pp. 899-916, 2018.

[72] S. Zhang, S. F. Cox, and M. S. Paterson, "The influence of room temperature deformation on porosity and permeability in calcite aggregates," Journal of Geophysical Research, vol. 99, no. B8, pp. 15761-15775, 1994.

[73] P. Gavrilenko and Y. Gueguen, "Fluid overpressures and pressure solution in the crust," Tectonophysics, vol. 217, no. 1-2, pp. 91-110, 1993.

[74] L. Mezri, L. Le Pourhiet, S. Wolf, and E. Burov, "New parametric implementation of metamorphic reactions limited by water content, impact on exhumation along detachment faults," Lithos, vol. 236-237, pp. 287-298, 2015.

[75] D. Norton and R. Knapp, "Transport phenomena in hydrothermal systems; the nature of porosity," American Journal of Science, vol. 277, no. 8, pp. 913-936, 1977.

[76] M. S. J. Mlynarczyk, R. L. Sherlock, and A. E. Williams-Jones, "San Rafael, Peru: geology and structure of the worlds richest tin lode," Mineralium Deposita, vol. 38, no. 5, pp. 555-567, 2003. 

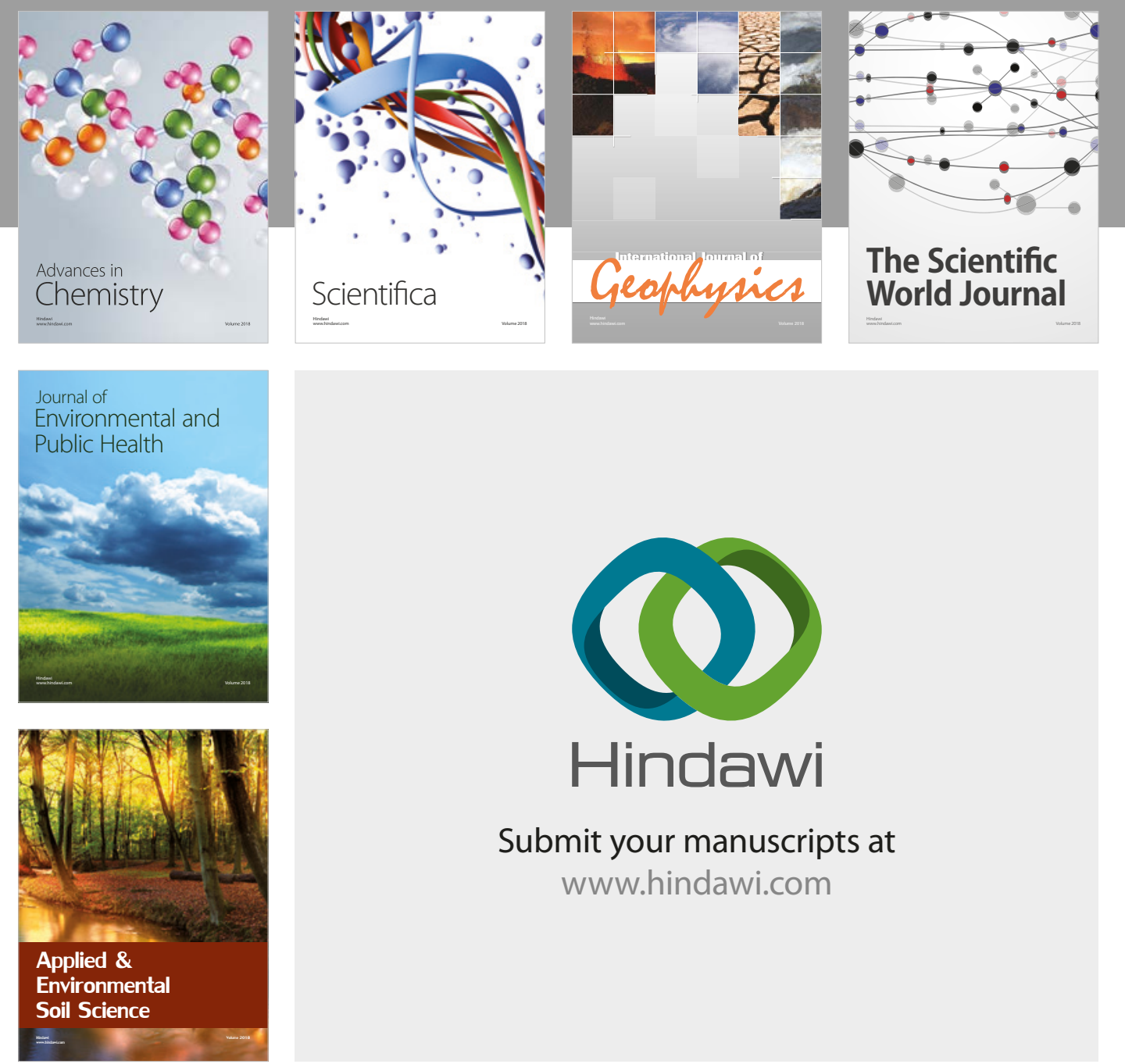

The Scientific

\section{World Journal}
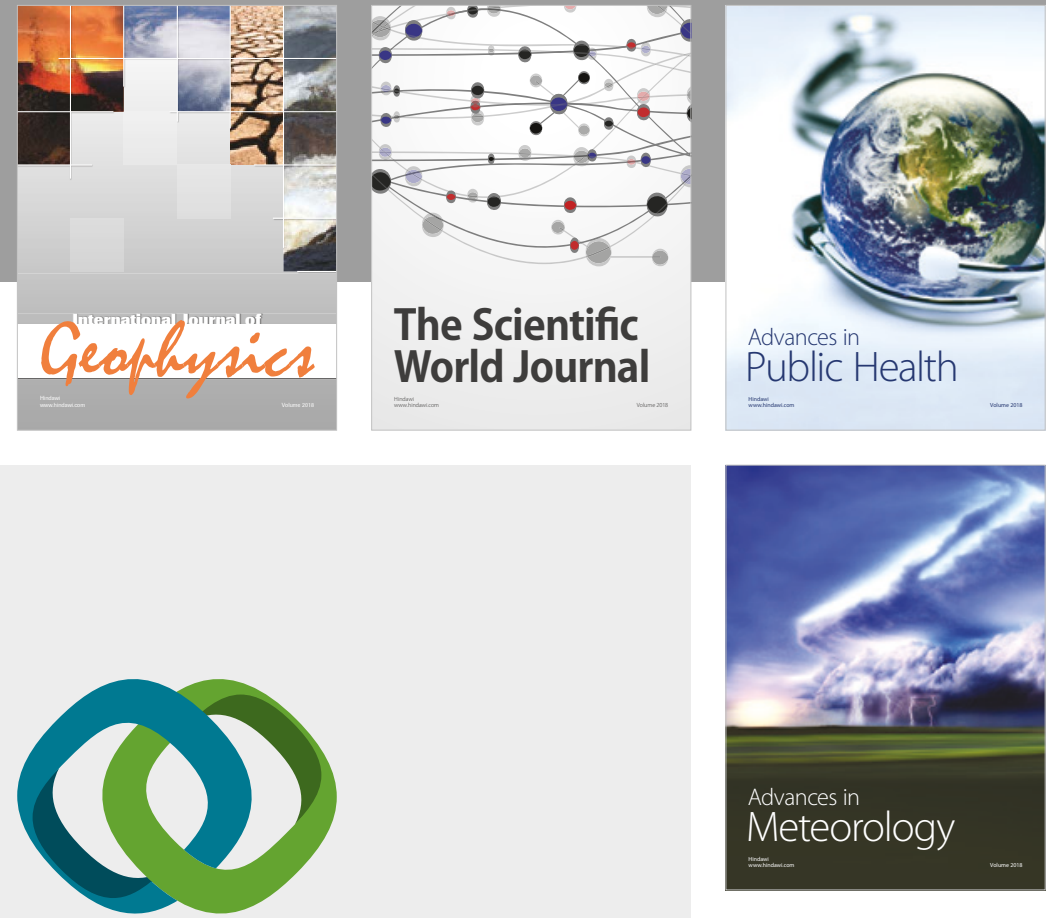

Advan

Public Health

\section{Hindawi}

Submit your manuscripts at

www.hindawi.com
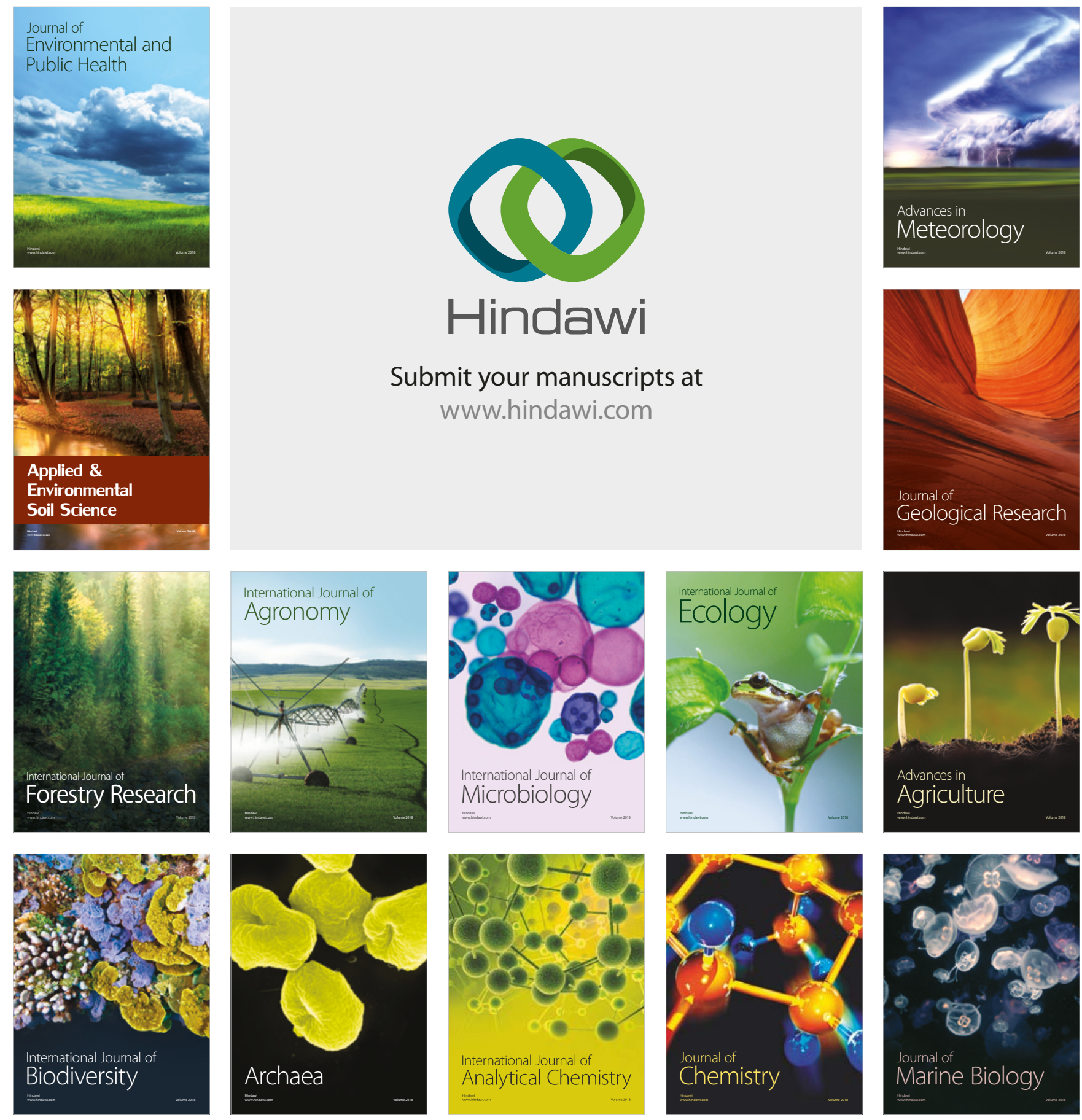